\title{
Review of the South African Agricultural Legislative Framework: Food Security Implications
}

\author{
Sheryl L Hendriks ${ }^{a}$ \& Nic J Olivier ${ }^{b}$ \\ ${ }^{a}$ Director, Institute for Food, Nutrition and Well-being and the Department of Agricultural Economics, Rural \\ Development and Agricultural Extension, University of Pretoria, Private Bag X20, Hatfield, Pretoria Gauteng \\ 0028, South Africa. \\ ${ }^{\mathrm{b}}$ Director, SADC Centre for Land-related, Regional and Development Law and Policy, Post-graduate School for \\ Agriculture and Rural Development, University of Pretoria, Private Bag X20, Hatfield, Pretoria 0028, South \\ Africa.
}

\begin{abstract}
Although South Africa has reported national food security for decades, current production patterns, land uncertainty and consumer preferences put future national household food insecurity in question. Household food insecurity in South Africa is at unacceptable levels. This paper reviews the country's agricultural legislative framework in terms of food security and the right to food. The review found that South African agricultural policies do not actively promote food security and the lack of enforceable food security policy makes it difficult to coordinate existing policies. The lack of food security legislation means that the right to food has no enforceable framework. A comprehensive food security policy and legislative framework and implementation strategy is urgently needed to address hunger and poverty to progressively achieve the targets set out for national growth and development and realise the right to food enshrined in the constitution.
\end{abstract}

Keywords: food security; legislation; policy; right to food; food insecurity

\section{Introduction}

As the period for achieving the Millennium Development Goals draws to a close, regional and international committees (African Union and NEPAD, 2009; High Level Task Force on the Global Food Security Crisis, 2010; Committee on World Food Security High Level Panel of Experts on Food Security and Nutrition (HLPE), 202a1; 2012b; United Nations, undated) are calling for comprehensive policy and legislative national food security frameworks to guide national progress on reducing food insecurity. The first United Nations Millennium Development Goal is to eradicate extreme poverty and hunger (UN, 2012). It is in this context that a review of the South African Agricultural Legislative Framework was undertaken to evaluate the consistency and convergence of agricultural legislation 
in support of national and household food security and the relaisation of the right to food as enshrined in South Africa's progressive constitution.

This paper investigates the agricultural legislative framework that (at least in theory) enables the establishment of comprehensive structures and systems that would assist in improving food security. Only legislation overseen by the Department for Agriculture, Forestry and Fisheries (DAFF) is reviewed. The background (section 2) is followed by an overview of the international and South African constitutional context (section 3) and of the current South African food security context (section 4). Section 5 provides a brief overview on the South African food policy context, providing a discussion of the contents and focus of the most important key policies and strategies. Section 6 identifies the need for an appropriate regulatory framework and implementation strategy for food security. Section 7, which gives an overview of DAFF's agricultural legislation relating to food security, and is followed (section 8) by a detailed structured review of the current and envisaged South African agricultural statutory context. The conclusion (section 9) deals with a number of key findings and related recommendations.

\section{Background}

Food security is defined as: "When all people, at all times, have physical and economic access to sufficient, safe and nutritious food to meet their dietary needs and food preferences for an active healthy life" (FAO, 1996). This definition covers four inter-related elements of availability, access, bio-utilisation and a stable supply of food. It infers that every person should be able to acquire food through growing their own food and purchasing foods they do not produce. Their consumption of food should be adequate to meet their nutritional needs as determined by age, sex, weight and height as well as the level of physical activity and biological factors. The definition goes beyond stating that every person should have enough food for today, but implies that all people should not have to worry about securing enough food to meet their needs in the future. The definition therefore infers the need for sustainable production, supply and incomes underpinned by sustainable livelihoods.

For too long, food security has been assumed present when countries have sufficient food to feed their people. This has long been the case for South Africa. The country is food secure at the aggregate national level, with adequate agricultural production to feed it population of 53 million 
people through a highly commercialized and efficient agricultural sector established before 1994 (Stats SA, 2012).

Commercial food production has largely sustained national food security, providing enough cereals to ensure a positive food balance as estimated by Food Balance Sheet estimates. Since 2007, the country has been a net importer of food in some years and a net exporter in other years. There are just over 40000 farmers feeding the nation, with over 1 million small farmers struggling to enter the formal sector (NDA, 2006, Stats SA 2006). Less than a quarter of the entire population engages in any form of agriculture (Stats SA, 2012). Land tenure uncertainty caused by land reform programme and high levels of political uncertainty places sustainable future food security situation under question.

Food security goes beyond having enough food to include food safety, adequate sanitation and appropriate risk management (AU/NEPAD, 2009). However, the narrow interpretation of food security has led to a dire neglect of essential elements of policy and strategy and the design and implementation of strategic programmes in South Africa to address the daily reality for between a third and a half of the nation's population (Stats SA, 2014). Food security is an outcome of complex inter-relationships and interactions of various parts of the food system (Eriksen, 2007) and social inequalities (Hendriks, 2014).

The consequences of widespread food insecurity threaten national security, significantly impair labour productivity and place a heavy burden on national health and social security systems. The human potential and productivity losses due to under-nutrition seriously constrains economic development, costing more than 10 per cent of individual lifetime earnings and accounting for two to three per cent loss of annual gross domestic product (World Bank 2006). The evidence in favour of improving nutrition is clear - even if based simply on the costs of not acting (Alderman, 2004; World Bank 2006):

- Underweight is the single largest risk factor contributing to the global burden of disease in the developing world, causing nearly $15 \%$ losses in total disability-adjusted life years in countries with high child mortality (Ezzati et al 2002; World Health Organization 2002).

- Malnutrition is directly or indirectly associated with nearly 60 per cent of all child mortality and even mildly underweight children have nearly double the risk of death of their wellnourished counterparts (Caulfield et al 2004). 
- Infants with low birth weight (less than 2.5 kilograms) are at 2 to 10 times the risk of death compared with normal birth weight infants. These same low birth weight infants are also at a higher risk of non-communicable diseases such as diabetes and cardiovascular disease in adulthood (Behrman, Alderman, and Hoddinott 2004).

- Vitamin A deficiency compromises the immune systems of approximately $40 \%$ of the developing world's children under age five, leading to the deaths of approximately one million young children each year (World Bank 2006).

- Severe iron deficiency anaemia causes the deaths in pregnancy and childbirth of more than 60,000 young women a year and leads to almost 18 million babies a year being mentally impaired with IQs that are at least 10 to 15 points lower than those not deficient (World Bank 2002).

- Maternal folate deficiency leads to a quarter of a million severe birth defects every year (UNICEF and MI 2004).

\section{International and South African Constitutional Context}

The right to food asserts that government has responsibilities to ensure that food is acceptable to a certain culture, supply is sustainable (environmentally and economically) and the access to food does not interfere with the enjoyment of other human rights. This right to food is set out in the Universal Declaration of Human Rights in 1948 and the International Covenant on Economic, Social and Cultural Rights (ICESCR) in 1966. Article 11.1 of the ICESCR states that parties recognise the right to food as part of the right of everyone to an adequate standard of living for himself and his family,

"Including adequate food, clothing and housing, and to the continuous improvement of living conditions".

In article 11.2, the fundamental right of everyone to be free from hunger and a commitment by State Parties to take "individually and through international cooperation, the measures, including specific programmes, which are needed" is recognized. In terms of article 11, the State's Parties are obliged to ensure adequate (access to) food and freedom from hunger (Brand, 2013:56C-6). In General Comment No. 12 (paragraph 15), the obligations of governments are to:

- Respect existing access to adequate food and requires that Parties do not adopt measures that could prevent such access

- Protect access to adequate food 
- Fulfill (facilitate) access to and use of resources and means to ensure sustainable livelihoods (of which food security is an outcome).

- Fulfill (provide) that right directly whenever an individual or group is unable to enjoy the right to adequate food.

The South African Constitution (Constitution of the Republic of South Africa, 1996) states in section 7(1) and (2) and in section 8 that the South African Government is obliged to uphold and implement the rights contained in the Bill of Rights:

"7(1) This Bill of Rights is a cornerstone of democracy in South Africa. It enshrines the right of all people in our country and affirms the democratic values of human dignity, equality and freedom.

(2) The State must respect, protect, promote and fulfil the rights in the Bill of Rights.

8(1) The Bill of Rights applies to all law, and binds the legislature, the executive, the judiciary and all organs of state" (RSA, 1996).

Section 24 provides everyone with the right to a clean environment:

"24 Everyone has the right-

(a) to an environment that is not harmful to their health or well-being; and

(b) to have the environment protected, for the benefit of present and future generations, through reasonable legislative and other measures that-

(i) prevent pollution and ecological degradation;

(ii) promote conservation; and

(iii) secure ecologically sustainable development and use of natural resources while promoting justifiable economic and social development (RSA, 1996).

The right to health care, food, water and social security is enshrined in section 27 , which also obliges the South African state to take reasonable legislative and other steps, within the context of its available resources, to progressively give content to each of these rights (the section therefor includes an internal limitation (Brand, 2013:56C-8)). In this regard, sections 27(1)(b) and 27(2) are relevant:

"27(1) everyone has the right to have access to - 
(b) Sufficient food and water; and

(2) The state must take reasonable legislative and other measures, within its available resources, to achieve the progressive realisation of these rights" (RSA, 1996).

In respect of children, section 28(1) of the Constitution determines that every child has the right, amongst others:

“(c) To basic nutrition, shelter, basic health care services and social services;

(d) To be protected from maltreatment, neglect, abuse or degradation". (RSA, 1996)

In the case of children, the section 28(1)(c) and (d) rights (including the right to basic nutrition) is not dependent on the availability of state resources; the obligation to ensure the full realisation of these rights (and other section 28 rights) is unqualified. Cognisance must also be taken of section 2 (the right to equality) and section 11 (the right to life).

There are two legs relevant to the right to food, namely (economic and physical) accessibility and sufficiency (the implementation of effective distribution systems by the State) (Van Bueren, 2013:2211). The constitutional right to food creates both duties and standards of justification and scrutiny. The State is obliged to protect the right to food and may not impair existing access to adequate food or make it difficult or impossible for people to gain access or enhance existing access to food (i.e. by implementing deliberately retrogressive measures). This is called a negative duty, even though it also has a positive aspect in that the State must take steps to protect the right from interference (Brand, 2013:56C-10, 15; Brickhill \& Ferreira, 2013:568-570; Rautenbach \& Malherbe, 2009:386). The State also has a duty to promote and fulfil the right to food by adopting relevant measures (including legislative, administrative and budgetary measures). This is called a positive duty (Brand, 2013:56C-21; Brickhill \& Ferreira, 2013:573-574, 591-592; Rautenbach \& Malherbe, 2009:386)). The reasonableness test must be applied to the section 27 right (are reasonable steps taken by the State (i.e. reasonable legislative and other measures), within the available resources, to achieve the progressive realisation of the right (with the duty on the State to move expeditiously and effectively)?) (Brand, 2013:56C-6 - 7; Rautenbach \& Malherbe, 2009:387).

According to Terblanche and Pienaar (2013), when the international and South African constitutional context is taken into account, food security can be described as the situation that follows when persons have physical, social and financial access to sufficient, healthy and wholesome food at all 
times to meet their diet and food preferences for an active and healthy life, whether such access is the result of an enabling environment and/or State or other provision as required by section $27(1)(b)$ of the Constitution (Terblanche \& Pienaar, 2013:244).

\section{The South African Food Security Context}

While national food security is not a currently concern in South Africa, unacceptable levels of household and individual food insecurity and under-nutrition should be a major concern of national government. The General Household Survey (Stats SA, 2014) includes two questions on the frequency of the experience of hunger (interpreted as vulnerability to hunger) among adults and children. These questions have been included in the survey since 2002. THe experience of hunger has declined from 23.8\% in 2002 to $11.4 \%$ in 2013 (Stats SA, 2014). Yet, 23.1\% of households experience difficulty in accessing food (Stats SA, 2014). However, no comprehensive or conclusive system for monitoring food security and nutrition exists in the country. Four national surveys have included questions related to hunger and food insecurity:

- The National Food Consumption Survey (NFCS) of children aged 1-9 years conducted in 1999 (Labadarios, 2000).

- National Food Consumption Survey (NFCS) Fortification Baseline conducted in 2005 (Labadarios et al. 2005)

- South African Social Attitudes Survey (SASAS) conducted in 2008 (Human Sciences Research Council, 2008).

- More recently the South African National Health and Nutrition Examination Survey or SANHANES - 1 (Shisana et al. 2013).

The findings depict the realities of the triple burden of malnutrition (under-nutrition, micronutrient deficiencies and over-weight). Although the questions asked and samples were not consistent, these are the only surveys with relevant national data (see Hendriks 2014 for a synopsis of the current food security situation and comparison of the results of the surveys listed above). No conclusive estimate of food insecurity in the country is available and current survey findings do not reflect the daily realities of hunger and deprivation and no surveillance system exists to monitor the situation.

\section{The South African Food Policy Context}


The drafting of a food security policy was commissioned in 1996, but never moved past a draft document. The White Paper on Agriculture is the closest South Africa has had to a food security policy. The White Paper came into operation in 1995 (RSA, 1995). Its purpose is to ensure equitable access to agriculture and promote the contribution of agriculture to the development of all communities, society at large and the national economy, in order to enhance income, food security, employment and quality of life in a sustainable manner. It views national and household food security as equally important, and to be addressed from a multidimensional point of view. Government should, therefore, support the full spectrum of production systems and practices, from urban food gardens and small-scale production for household income and food security to largescale production systems. The White Paper states that:

- Productive agricultural land should be retained for agricultural use,

- Government will promote the establishment of a plant genetic resource programme to protect those plant species - in particular those that are essential in maintaining national food security.

- Comprehensive information is needed for the formulation of trade policy and to ensure national food security.

The Green Paper on Land Reform was released in 2011. The principles that underpin the Green Paper are decentralising the rural economy; democratic and equitable land allocation and use across race, gender and class; and a sustained production discipline for food security (RSA, 2011:11). The Green Paper attempts to improve on past and current land reform perspectives, without significantly disrupting agricultural production and food security; and, to avoid or minimise land redistribution and restitution which do not generate sustainable livelihoods, employment and incomes. In terms of the Constitution and the 1997 White Paper on South African Land Policy, the South African Government has to implement three land reform programmes. Firstly, the restitution programme (section 25(7) of the Constitution and the Restitution of Land Rights Act 22 of 1994, as amended in 2014) aims to restore land to those who had been dispossessed of land on account of race-based legislation or administrative practices. Beneficiaries include individuals, groups and communities, or those whose ancestors had been dispossessed as stated. Secondly, the redistribution programme (section 25(5) of the Constitution and the Provision of Land and Assistance Act 126 of 1993) provides support in order to enable persons to access to land on an equitable basis. Thirdly, the tenure reform programme (section 25(6) of the Constitution, the Extension of Security of Tenure Act 62 of 1997, the Land Reform (Labour Tenants) Act 3 of 1996 and the Interim Protection of Informal Land Rights Act 31 of 1996) aims to strengthen the security of tenure of individuals, groups and 
communities whose tenure was insecure as a result of past race-based legislation or administrative practices.

As regards improving the security of communal tenure, the Communal Land Rights Act 11 of 2004 was assented to on 14 July 2014, but was subsequently declared unconstitutional by the Constitutional Court in 2010 (see Tongoane and Others v Minister of Agriculture and Land Affairs and Others 2010 (6) SA 214 (CC)), as the wrong parliamentary process had been followed. No new draft legislation has since been submitted to Parliament.

The Integrated Food Security Strategy (IFSS) was adopted in 2002 (National Department of Agriculture (NDA), 2002), based on the FAO Special Programme for Food Security Guide for such strategies. It considered a failure, with very little integration of Ministries, no real implementation and no functional coordination structure (Perriera and Ruysenaar, 2012; Drimie and Ruysenar, 2010). The strategy aims to eradicate hunger, malnutrition and food security by 2015 and outlines the following strategic objectives to:

- Increase household food production and trading

- Improve income generation and job creation opportunities

- Improve nutrition and food safety

- Increase safety nets and food emergencies management systems

- Improve analysis and information management systems

- Provide capacity building

- Hold stakeholder dialogues (NDA, 2002).

However, the IFSS has not been widely implemented, largely due to a lack of sectoral coordination (Perriera and Ruysenaar, 2012; Drimie and Ruysenar, 2010).. Notwithstanding the above, a number of past and current policies and programmes contain elements relating to food security. For example, the Reconstruction and Development Programme (RDP) (RSA 1994, 53) that was launched in the early post-1994 era to address poverty and inequality aimed at improviong living conditions and stimulating economic growth The Integrated Sustainable Rural Development Strategy (ISRDS) was published in 2000 (RSA, 2000) was designed to foster social cohesion with strong institutions, sustainable economies and access to essential services.The Land Redistribution for Agricultural Development (LRAD) initiative was launched in 2001, and is a sub-programme of the Redistribution Programme of the Department of Land Affairs, which is jointly run by the Department of Land Affairs and the Department of Agriculture (RSA, 2001). The programme sought to allow previously 
disadvantaged communities to buy land and agricultural implements to establish agricultural livelihoods and boost food production at community level. The Comprehensive Agricultural Support Programme (CASP) (DAFF, 2004). CASP was prioritized for implementation during 2004 and sought to provide post-settlement support for the beneficiaries of land reform and private land acquisitions to encourage value-adding enterprises. The War on Poverty Programme was launched in 2008 (PMG, 2009) as an urgent short-term measure to bring together a menu of interventions that were already in place but gave greater prominence to this presidential priority. The central element of the campaign was to visit households and determine the conditions in which poor households exist, and identify specific interventions that could alleviate the conditions.

The Comprehensive Rural Development Programme (CRDP) was launched in August 2009, to tackle issues such as underdevelopment, hunger, poverty, joblessness, lack of basic services and other social ills in rural areas (RSA, 2009b: 4).

The new Growth Path is aimed at enhancing growth, employment creation and equity (RSA, 2010a). It recognizes that creating decent work opportunities, reducing inequality and defeating poverty can only happen through higher levels of economic growth that provides labour opportunities (RSA, 2010a:1). The New Growth Path sets out a range of measures to achieve employment targets, such as restructuring land reform to support smallholder schemes with comprehensive infrastructure, marketing, finance, and extension services support; upgrading employment in commercial agriculture; supporting growth in commercial farming and addressing price fluctuations in maize and wheat while supporting national food security; accelerating land claims processes and improving post-settlement support; implementing programmes to ensure competitive pricing of inputs; and supporting fishing and aquaculture (RSA, 2010a:12). In addition, Government will increase its support to small-scale agriculture by establishing community food gardens, marketing and service coops as well as accessible banking facilities (RSA, 2010a:14).

The National Development Plan (NDP) was published in 2012 and aims to eliminate income poverty by 2030 (by reducing the proportion of households with a monthly income of less than R419 per person (in 2009 prices) from 39 per cent to 0 per cent) and to reduce inequality (a reduction in the Gini coefficient from 0.69 to 0.6 by 2030) (RSA, 2012:34). Ensuring quality access to basic services, health care, education and food security (which includes both household food and nutrition security) are key issues to be addressed in building an integrated and inclusive rural economy. In this regard, the Plan proposes a reduction in the cost of living for low-income and working-class households (including a reduction in the cost of food) (RSA, 2012:40). In addition, it proposes a commitment to 
household food and nutrition security involving both public and private sector action in order to achieve broader social security coverage (RSA, 2012:53).

The Plan states that South Africa should aim to "maintain a positive trade balance for primary and processed agricultural products, and not to achieve food self-sufficiency in staple foods at all costs." In this regard, regional cooperation and regional expansion of production are favourable (RSA, 2012:231). According to the Plan, the ability to access food determines household food security. As such, job creation, agricultural productivity, as well as the provision of assistance to poor households to cope with increases in food prices are important. In addition, public works programmes should be utilized and expanded for rural infrastructure development, and access to social grants for eligible households should be provided. Taking into account that households spend approximately 35 per cent of their income on food (far more than the 3 per cent spent by upper-income households), measures should be investigated to close the urban/rural food-price gap (RSA 2012:231).. The Plan also stresses that any food security strategy should ensure that increased agricultural employment and rural incomes translate into improved nutrition (RSA 2012:231).

In October 2013, Cabinet passed the South African National Food and Nutrition Security Policy (Department for Social Development (DSD) and Department for Agriculture, Forestry and Fisheries (DAFF), 2013). The policy was gazetted on 22 August 2014. This sets out five pillars for achieving food security namely: availability of improved nutritional safety nets, improved nutrition education, alignment of investment in agriculture towards local economic development, improved market participation of the emerging agricultural sector, and risk management. However, the Policy lacks a legislative framework and implementation strategy necessary to achieve its goals.

\section{The need for a regulatory framework and implementation strategy for food security}

Policy as such is not legally binding and is not enforceable. According to the South African state administration model, any policy must be followed by legislation. The line functionary departments concerned must then submit their annual performance plans (APPs), setting out the programmes (and detailed projects) as well as their requests for funding. Thereafter, the legislature concerned (national parliament of provincial legislature, as the case may be) considers such APP, and expenditure is then approved by said legislature. 
Governments have an obligation to adopt legislative measures to give effect to constitutional rights in order to respect, protect, promote and fulfil the rights afforded to citizens. Such legislation provides a sound framework for the evaluation of existing policies, strategies and programmes and a mechanism for ensuring alignment and compliance of these with human rights and the overall commitments of government. This is even more so in a country like South Africa, where most legislation has been inherited from the previous apartheid system - the very system that created the dramatic inequalities that explain food security in the new South Africa. Since 1996, limited legislative reform has been carried out to realign past policies in ways that address the structural inequalities of the past. A few examples (examined below) of more recent Bills and draft Acts demonstrates how revisions of legislation can address these inequalities.

However, adjustments in existing individual Acts do not lead to the coherence and consolidation of crosscutting food policy issues that will ensure food security for the country. In addition to a comprehensive food security policy which provides the benchmark and review framework to ensure that legislative reform and national plans, strategies and programmes facilitate, protect and promote future food security, there is a need for concomitant legislation and an implementation strategy.

A food security Act will entrench the right to access to food and will form the framework to obtain dedicated food security related funding for programmes and projects specified in respective departments' APPs. It will provide the basis for cooperation between government departments and other entities, and will also provide for enforcement mechanisms to ensure that relevant provisions are adhered to. The Act should include a mix of instruments to fulfil basic human rights, identification of beneficiaries, targeting and registration methodologies, institutional arrangements, delivery mechanisms, accountability systems, and a sound monitoring and evaluation system that includes continuous surveillance of hunger and poverty levels, and should provide for mandatory early warning systems and contingency plans (including insurance mechanisms and requirements, emergency response systems and compensation schemes for disasters). The Act should also include an appeals mechanism.

An implementation strategy will provide a framework setting out the detailed institutional responsibilities, timeframes, deliverables, expected outputs and outcomes and an appropriate monitoring and evaluation system to ensure a phased approach with set deadlines which is binding on all stakeholders. 


\section{Overview of South African legislation related to agriculture and food security}

In the post 1994 period, there was considerable activity in drafting of strategic documents by the newly appointed post apartheid Ministries and Provincial Departments. Each Ministry set out to draft a green and then white paper. These have seen various iterations over the 15 years. The composition of Ministries related to Agriculture has changed at least three times in the postapartheid era. The current Provincial Departments of Agriculture do not directly with the National Ministries. Members of Parliament from Provinces report to multiple National Ministries - primarily Agriculture, Forestry and Fisheries (DAFF), Water Affairs, Rural Development and Land Reform, Trade and Industry and Public Works.

Continual restructuring within government has led to perpetual changes in leadership. This has led to instability and a situation where a high proportion of leadership positions are filled by acting incumbents. Therefore, very few strategies in the agriculture, rural development and related sectors being implemented and even fewer translated into legislation.

Agricultural legislation relevant to food security includes:

- Agricultural Pests Act 36 of 1993

- Agricultural Products Standards Act 119 of 1990

- Agricultural Research Ac 86 of 1990

- Animal Diseases Act 35 of 1984

- Animal Health Act of 2002

- Animal Identification Act 6 of 2002

- Animal Improvement Act 62 of 1998

- Conservation of Agricultural Resources Act 43 of 1983

- Fertilizers, Farm feeds, Agricultural Remedies and Stock Remedies Act 36 of 1947

- Meat Safety Act 40 of 2000

- Plant Breeders Rights Act 15 of 1976

- Plant Improvement Act 53 of 1976

- Subdivision of Agricultural Land Act 70 of 1970 
No agricultural policies were passed between 1996 and 2010. The following draft strategies, policies and legislation relevant to food security are currently under consideration (many are not available for public review):

- Draft Rural Development Strategy

- Draft Policy on the Expropriation Bill. This policy hopes to generate sufficient public interest in the debate on the principles that should inform the new expropriation bill and allows for a consultative and participatory process.

- Memorandum on the Objects of the Land Tenure Security Bill, 2010. Section 25(6) of the Constitution of the Republic of South Africa, 1996, entitles persons whose land tenure is legally insecure as a result of past racially discriminatory laws and practices, either to legally secure tenure or comparable redress.

- Plant Breeders' Rights Amendment Bill, 2013, provides a system where under plant breeders' rights relating to varieties of certain kinds of plants may be granted and set soy the requirements that have to be complied with for the grant of such rights.

- Agricultural Produce Agents Bill, 2003.

- National Pound Bill, 2012.

- Fertilizer and Feeds Bill, 2013.

- Marine Living Resources Amendment Bill, 2013.

- National Bill for Agricultural Training Institutes of South Africa, 2012.

- Protection and Development of Agricultural Land Framework Bill, 2013. This Bill will provide for the sustainable use of natural agricultural resources, including control over the subdivision and change of use of agricultural land, with reference to high value and medium value agricultural land in support of biodiversity.

- The Transfer of Rights Policy was gazetted in 2010.

- The Small-scale Fisheries Policy was gazetted in 2011.

- The Policy on the Transfer of Commercial Fishing Rights was published and gazetted in 2010. This programme continued with the granting of interim relief measures pertaining to exemptions/permits.

- The list of protected trees under the National Forest Act was gazetted for public comment, 2010.

- The Pesticides Policy was approved by the Minister and gazette in 2010

- The Draft Policy on Organic Agriculture is currently at a stakeholder consultative stage.

- A discussion document was finalised towards the provision of primary plant health diagnostic services in rural areas in partnership with the Agricultural Research Council. 
- The South African National Food and Nutrition Security Policy (DSD and DAFF, 2013) was approved by Cabinet in September 2013 and gazette on 22 August 2014.

\section{Review of South African agricultural legislation related to food security}

Appendix A provides a matrix analysing the relevance of the Acts against government priorities (the Presidential Outcomes) with reference to food security, while Appendix B provides an analysis of the Acts against key policy considerations for food security as outlined in the Comprehensive African Agricultural Development Programme (CAADP) Framework for African Food Security (FAFS) (AU/NEPAD, 2009). A summary of the existing Acts is presented in Table 1. A table of extracts of the South African agricultural legislation with relevance to food security can be found in the attached file (this will be published separately on a website and the URL provided here if this paper is accepted for publication). While it is acknowledged that other sector policies affect food security, the current review focuses only on legislation administered by the Department for Agriculture, Forestry and Fisheries.

[Insert Table 1 here]

The Marketing of Agricultural Products Amendment Act 47 of 1996, the Marine Living Resources Act 18 of 1998, the Marine Living Resources Amendment Bill, 2013 and the National Forest Act 84 of 1998 make deliberate efforts to provide for inclusive growth across the spectrum of small and commercial production and trade. These address a far higher number of government priorities than any other.

The Marketing of Agricultural Products Act 47 of 1996 sets out the regulatory framework for the establishment and enforcement of regulations related to the marketing of agricultural products. This Act has a direct and important role in food security, safeguarding against statutory measures that affect food in security and unemployment in South Africa. It seeks to increase market participation for all producers, improve efficiencies, optimise export earnings and improve the viability of the agricultural sector.

The amendments presented in the Draft Marketing of Agricultural Products Amendment Bill, 2013 provide greater alignment with government policies, with a social focus on the role of smallholders 
Table 1: Summary of South African agricultural legislation with regard to food security and the right to food

\begin{tabular}{|c|c|c|c|c|c|c|c|c|c|c|c|c|c|c|c|c|c|c|c|c|c|c|c|}
\hline \multirow[t]{7}{*}{ 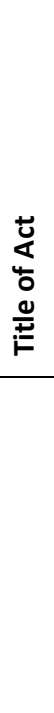 } & 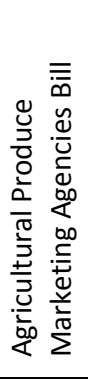 & 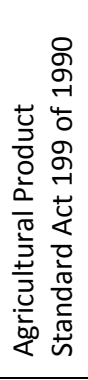 & 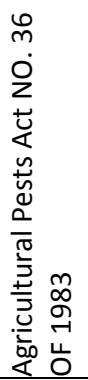 & 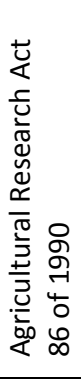 & 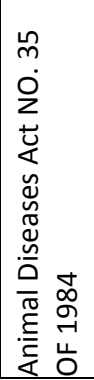 & 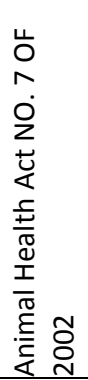 & 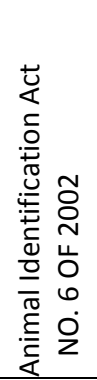 & 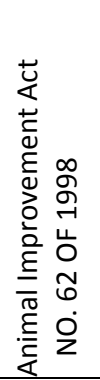 & 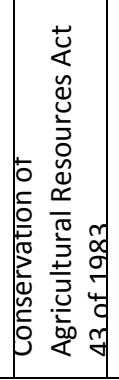 & 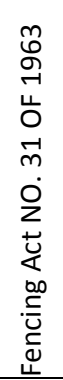 & 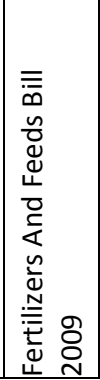 & 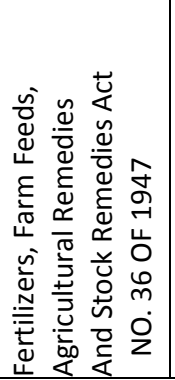 & 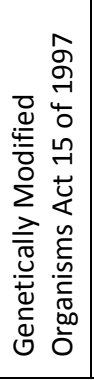 & 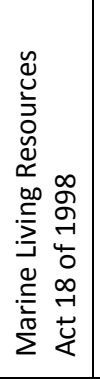 & 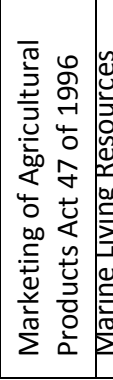 & 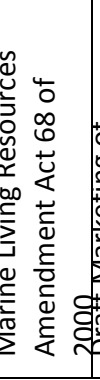 & 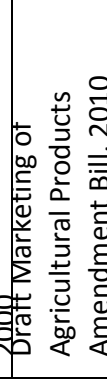 & 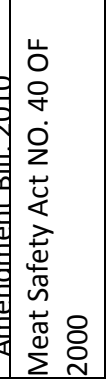 & 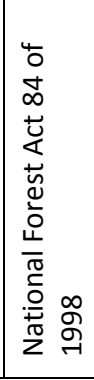 & 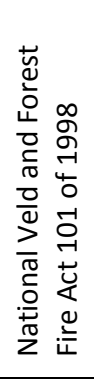 & 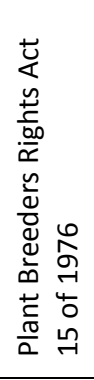 & 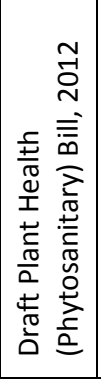 & 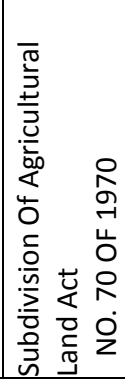 \\
\hline & \multicolumn{23}{|c|}{ Acts that play a protective role with regard to national food security - mainly in terms of reducing the agricultural and trade risk and ensuring food safety } \\
\hline & & $\mathrm{x}$ & $\mathrm{X}$ & & $\mathrm{X}$ & $\mathrm{X}$ & $\mathrm{X}$ & & \begin{tabular}{|l|l|l}
$x$ & \\
\end{tabular} & $\mathrm{X}$ & $\mathrm{X}$ & $\mathrm{X}$ & & & & & & $\mathrm{X}$ & & $\mathrm{X}$ & & $\mathrm{X}$ & \\
\hline & \multicolumn{23}{|c|}{$\begin{array}{l}\text { Acts seek to manage and regulate crop and breed improvement - such activities have benefits for improving the productivity and levels of production of agriculture to increase } \\
\text { the amount of food available. These Acts include regulations to safeguard the quality of food. }\end{array}$} \\
\hline & & & & $\mathrm{x}$ & & & & $\mathrm{x}$ & & & & & $\mathrm{X}$ & & & $\mathrm{X}$ & & & & & $\mathrm{X}$ & & \\
\hline & \multicolumn{23}{|c|}{ The following Acts have elements that seek to improve the efficiency of the agricultural production and trade system } \\
\hline & & & & & & & & & & & & & & & & $\mathrm{X}$ & $\mathrm{X}$ & & & & & & \\
\hline
\end{tabular}


in the agricultural sector and ensuring that these players have access to markets, training and support.

So too, the Marine Living Resources Act 18 of 1998, (as amended in 2000) - to be further amended by means of the Marine Living Resources Amendment Bill, 2013 - provides for greater protection and provision of opportunities for the livelihoods of small players and addresses issues directly related to ensuring equitable access to natural resources, conservation of resources to ensure sustainable food system and livelihoods in future and attempts to address inequalities. The National Forest Act 84 of 1998 includes a section on Community Forestry. These two Acts also make provision for compensation in the case of emergencies and disasters with reference to livelihoods.

However, the Marine Living Resources Act 18 of 1998 fails to adequately address an emerging interest in aquaculture and in-land fish production. This has been identified as a rich source of protein with potential for sustainable livelihood development in rural areas of the country to address under-nutrition.

No clear conflicts are evident in the existing legislation with regard to food security. The current legislation adopts a 'do no harm' approach in protecting national food security and safety. Most Acts and Bills reviewed plays a role in reducing risk of food insecurity, food safety, public health, production and marketing. Only the Marine Living Resources Act 18 of 1998 and the National Forest Act 84 of 1998 look at transformative roles of government and policy, many custodial roles are set out related to protecting production, food safety and marketing.

While the legislation plays a protective role with regard to food production, marketing safety, little is addressed regarding improving the nutrition profile of South Africans. Some legislation may pose constraints to -

- small businesses (the Meat Safety Act 40 of 2000's restrictions related to abattoirs and slaughter of animals), and

- small producers (the current Subdivision of Agricultural Land Act 70 of 1970 regarding division of commercial-sized farms (to be replaced by the Protection and Development of Agricultural Land Framework Bill, 2013), and the Animal Identification Act 6 of 2002 that requires registration and tagging), restricting engagement by small producers or incurring costs for poorer segments of society. 
Just less than half the Acts and Bills reviewed had some mention or role in sustainable resource management. The Conservation of Agricultural Resources Act 43 of 1983, the Marine Living and Resources Act 18 of 1998 and the National Forest Act 84 of 1998 have elements of environmental protection and conservation. There is some mention of sustainable livelihoods and increasing access to income opportunities in these Acts, but on the whole, few Acts and Bills contribute directly to Presidential Outcomes 4 (Decent employment through inclusive economic growth) and 7 (Vibrant, equitable and sustainable rural communities with food security for all).

Ensuring food security in South Africa has been entrusted to the Department of Agriculture, Forestry and Fisheries (DAFF), yet the only legislation under the jurisdiction of DAFF that directly mentions food security is the Marketing of Agricultural Products Act 47 of 1996, adopting a 'do no harm' requirement in the consideration of statutory measures. The criteria are used to judge this are not set out and government interpretation of food security (national or household) is not definitive.

The lack of food security legislation means that the right to food has no enforceable framework. No mechanisms for ensuring individual and household food security is provided. While the Marketing of Agricultural Products Amendment Bill, 2013, the Marine Living Resources Act 18 of 1998 (as amended in 2000 and to be further amended in 2013) and the National Forest Act 84 of 1998 make special mention of small producers and businesses and the promotion of economic growth and employment creation, no provision for addressing the structural inequalities that cause food insecurity in South Africa, reneging on DAFF and government's responsibility to respect, provide, protect and fulfil the basic human rights of the food insecure. Although Social Development Income Grants and Food Parcels, the Department of Education's School Feeding Programmes and the Public Works Food/Water-for-Work Programmes offer some relief to those suffering or susceptible to hunger and poverty, these programmes do not provide a comprehensive approach to food security and are by no means legally enforceable due to the lack of a comprehensive food security legislative framework.

\section{Conclusion}

An enforceable and comprehensive food security policy and legislative framework and implementation strategy is urgently needed in South Africa to guide the establishment of a comprehensive national food security strategy and appropriate programmes to address hunger and 
poverty to progressively achieve the targets set out for national growth and development and realise the right to food enshrined in the constitution. . Having sound legislation sets the framework for enforcement, but society is only protected if these laws and regulations are enforced and fair appeal processes are accessible to all citizens.Such a framework will assist in the review of existing policies and legislation and the implementation of more food security sensitive Acts in future.

\section{References}

African Union/New Partnership for Africa's Development 2009 Comprehensive African Agricultural Development Programme Framework for African Food Security. http://www.caadp.net/pdf/CAADP\%2OFAFS\%20BROCHURE\%20indd.pdf. Accessed 6 August 2012.

Alderman, H. (2004). The economic cost of a poor start to life. Journal of Developmental Origins of Health and Disease; 1 (1); 19-25.

Behrman JR, Alderman H, and Hoddinott J 2004 Nutrition and Hunger. In Global Crises, Global Solutions, ed. Bjorn Lomborg. Cambridge, UK: Cambridge University Press.

Brand D, 2013. Food. In Woolman S \& Bishop M (Eds.), Constitutional Law of South Africa. 2nd edn. Juta, Cape Town.

Brickhill J \& and Ferreira N, 2013. Socio-economic Rights. In Curry I \& de Waal J (Eds.), The Bill of Rights Handbook. 6th edn. Juta, Cape Town.

Caulfield LE, de Onis M, Blössner M, Black RE 2004 Under nutrition as an Underlying Cause of Child Deaths Associated with Diarrhoea, Pneumonia, Malaria, and Measles. American Journal of Clinical Nutrition 80: 193-98.

Committee on World Food Security High Level Panel of Experts (2012). Climate change and food security. Committee on World Food Security High Level Panel of Experts, Rome.

Committee on World Food Security High Level Panel of Experts (HLPE, 2012). Social Protection for food security. Committee on World Food Security High Level Panel of Experts, Rome. 
Department of Agriculture, Forestry and Fisheries (DAFF, 2004). The Comprehensive Agricultural Support Programme (CASP). Available from: http://www.nda.agric.za/docs/CASP/casp.htm. Accessed 12 August 2012.

Department for Social Development and Department for Agriculture, Forestry and Fisheries (2013). South African National Food and Nutrition Security Policy. http://www.daff.gov.za/docs/media/NATIONAL\%20POLICYon\%20food\%20and\%20nutrirition\%20sec urity.pdf . Accessed 11 February 2014.

Drimie, S and Ruysenaar, S (2010). The Integrated Food Security Strategy of South Africa: An institutional analysis. Agrekon, 49 (3): $316-337$.

Ericksen, PJ. (2007). Concpetualising food systems for global environmental change. Global Environmental Change (2007). Doi: 10.1016/j.gloenvcha.2007.09.002.

Ezzati M, Lopez A, Rodgers A, Vander Hoorn S, Murray C, the Comparative Risk Assessment Collaborating Group. (2002). Selected Major Risk Factors and Global and Regional Burden of Disease. Lancet 360(9343): 1-14.

FAO (Food and Agricultural Organisation) (2006). The State of Food Insecurity in the World 2006. ftp://ftp.fao.org/es/ESA/policybriefs/pb_02.pdf. Accessed 29 August 2012.

Hendriks SL (2014). Food security in South Africa: Status quo and policy imperatives. Paper accepted for publication in Agrekon, 53 (2): 1 - 24.

High Level Task Force on the Global Food Security Crisis 2010 Updated Comprehensive Framework For Action on Food Security. High-Level Task Force on the Global Food Security Crisis, United Nations, Rome.

Human Sciences Research Council (2008). South African Social Attitudes Survey (SASAS). Pretoria: Human Sciences Research Council; 2008. Available from: www.hsrc.ac.za [accessed 29 August 2012]. 
Labadarios D, 2000. The National Food Consumption Survey (NFCS): children aged 1-9 years, South Africa, 1999. Stellenbosch; Directorate: Nutrition, Department of Health, National Food Consumption Survey Consortium.

Labadarios D, Mchiza ZJ, Steyn NP, Gericke G, Maunder EMW, Davids YD \& Parker W (2011). Food Security in South Africa: A review of National Surveys. Bulletin of the World Health Organization. Available from: http://www.who.int/bulletin/volumes/89/12/11-089243.pdf. Accessed 20 August 2012.

National Department of Agriculture (NDA 2002). Integrated Food Security Strategy. Pretoria, NDA. Available from: http://www.fao.org/righttofood/inaction/countrylist/SouthAfrica/IntegratedFoodSecurityStrategy_2 002.pdf. Accessed 15 August 2012.

PMG (Parliamentary Monitoring Group) (2009) The War on Poverty. www.pmg.org.za/docs/2009/091013waronpoverty-edit.pdf. Accessed 4 April 2013.

Pereira, LM and Ruysenaar, s. (2012). Moving from traditional to new adaptive governance: the chnginf face of food security responses in South Africa. Food Security, 4:41 - 58 .

Rautenbach IM \& Malherbe EFJ, 2009. The Bill of Rights in Constitutional Law. 5th edn. LexisNexis, Morningside.

RSA (Republic of South Africa) (1995). White Paper on Agriculture. http://www.nda.agric.za/docs/Policy/WHITEPAPER.htm. Accessed 4 April 2013.

RSA (Republic of South Africa) (1996). Constitution of the Republic of South Africa. http://www.info.gov.za/documents/constitution/1996/a108-96.pdf. Accessed 4 April 2013.

RSA (Republic of South Africa) (2000). Integrated Sustainable Rural Development Strategy. http://www.info.gov.za/otherdocs/2000/isrds.pdf. Accessed 4 April 2013.

RSA (Republic of South Africa) (2000). Land Redistribution for Agricultural Development: A Sub$\begin{array}{llll}\text { Programme of the Rand Programme. } & \text { Redistribution P P }\end{array}$ 
http://www.ruraldevelopment.gov.za/phocadownload/Land_Acquisition_Warehouse/land\%20redist ribution\%20for\%20agricultural\%20development.pdf. Accessed 4 April 2013.

RSA (Republic of South Africa) (2009a). Comprehensive Rural Development Programme Framework. http://www.ruraldevelopment.gov.za/about-us/crdp/crdp-documents/file/670. Accessed 4 April 2013.

RSA (Republic of South Africa) (2009b). Medium Term Strategic Framework 2009 - 2014. http://www.info.gov.za/view/DownloadFileAction?id=103901. Accessed 4 April 2013.

RSA (Republic of South Africa) (2010a). New Growth Path.

file://C:/Users/Purco/Downloads/NGP\%20Framework\%20for\%20public\%20release\%20FINAL_1.pdf . Accessed 28 August 2014.

RSA (Republic of South Africa) (2011). Green Paper on Land Reform. http://www.info.gov.za/view/DownloadFileAction?id=151707. Accessed 4 April 2013.

RSA (Republic of South Africa) (2012). National Development Plan. http://www.npconline.co.za/MediaLib/Downloads/Downloads/NDP\%202030\%20\%200ur\%20future\%20-\%20make\%20it\%20work.pdf. Accessed 4 April 2013.

RSA (Republic of South Africa) (1994). White Paper on Reconstruction and Development. http://www.info.gov.za/view/DownloadFileAction?id=70427. Accessed 4 April 2013.

Shisana O, Labadarios D, Rehle T, Simbayi L, Zuma K, Dhansay A, Reddy P, Parker W, Hoosain E, Naidoo P, Hongoro C, Mchiza Z, Steyn NP, Dwane N, Makoae M, Maluleke T, Ramlagan S, Zungu N, Evans MG, Jacobs L, Faber M, \& SANHANES - 1 Team (2013) South African National Health and Nutrition Examination Survey (SANHANES - 1). Cape Town: HSRC Press.

Statistics South Africa (StatsSA 2014). General Household Survey 2014. Pretoria, Stats SA.

Statistics South Africa, (StatsSA), (2006). Migration and urbanisation in South Africa. Report no. 0304-02 (2006), Pretoria, South Africa. 
Terblanche A \& Pienaar GJ, 2012. Raamwerkwetgewing ter Verwesenliking van die Reg op Toegang tot Voldoende Voedsel. Potchefstroom Electronic Law Journal 15(5): 229 - 268.

UN (United Nations) (2012). The Millennium Development Goals Report. http://mdgs.un.org/unsd/mdg/Resources/Static/Products/Progress2012/English2012.pdf. Accessed 4 April 2013.

UNICEF and Micronutrient Initiative (MI, 2004). Vitamin and Mineral Deficiency: A Global Damage Assessment Report. http://www.unicef.org/media/files/davos_micronutrient.pdf. Accessed 5 August 2012.

United Nations (undated). Scaling Up Nutrition: A Framework for Action. United Nations, Geneva.

Van Bueren G, 2013. Health. In Cheadle H, Davis D \& Haysom N (Eds.), South African Constitutional Law: The Bill of Rights. 2nd edn. LexisNexis, Morningside.

World Bank (2006). Repositioning Nutrition as Central to Development: A Strategy for Large-Scale Action. The World Bank, Washington DC.

World Health Organisation (2002). World Health Report 2002: Reducing Risks, Promoting Healthy Life. Geneva: WHO. 
Appendix A: Summary of legislation with impact on food-security related outcome

\begin{tabular}{|c|c|c|c|c|c|c|c|c|c|c|c|c|c|c|c|c|c|c|c|c|c|c|c|c|}
\hline $\begin{array}{l}\text { South African priorities } \\
\text { and strategies }\end{array}$ & 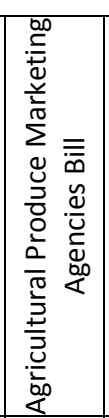 & 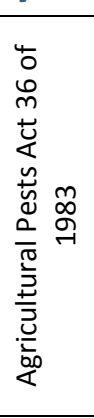 & 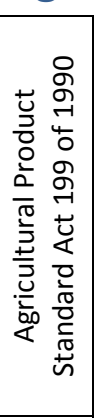 & 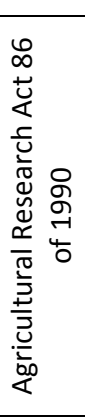 & 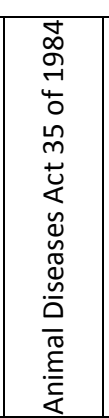 & 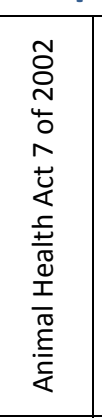 & 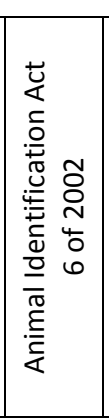 & 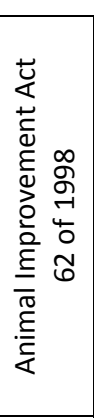 & 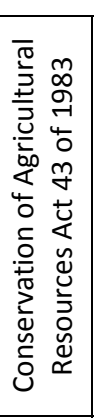 & 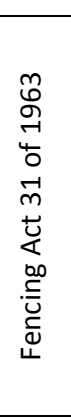 & 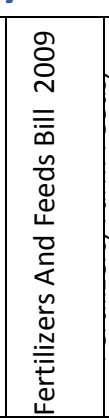 & 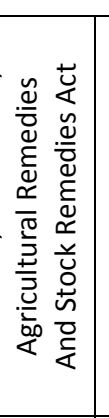 & 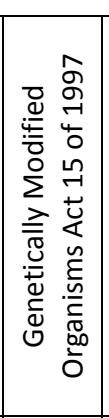 & 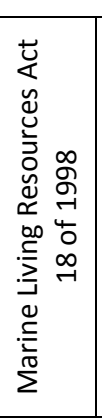 & 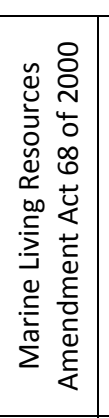 & 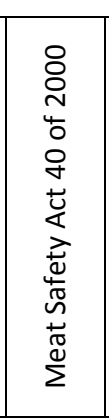 & 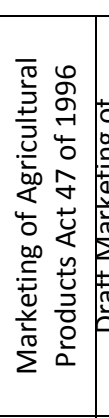 & 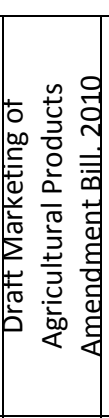 & 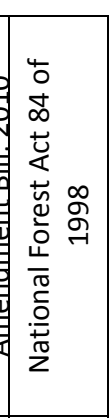 & 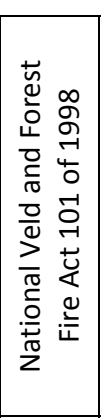 & 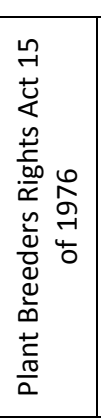 & 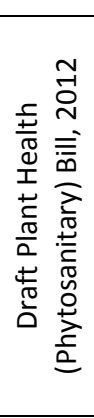 & 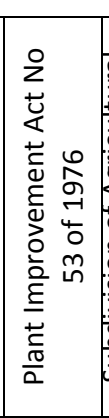 & 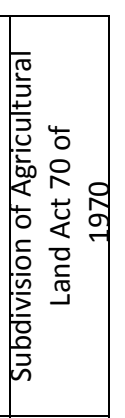 \\
\hline $\begin{array}{l}\text { 1. Transformational, } \\
\text { developmental and } \\
\text { custodial objectives }\end{array}$ & Prepare & $5 \& 6$ & $3 \& 4$ & & Preamble & Dreamble & & & 5,6 & & Preamble & Sreamblep & Preamble & Sreamble & $S 2 c$ & & 3 & & preamble & & S27 & $\begin{array}{c}S 19 \& \\
10\end{array}$ & reamble & \\
\hline \multicolumn{25}{|l|}{$\begin{array}{l}\text { 2. RSA Government } \\
\text { Strategic Priorities }\end{array}$} \\
\hline $\begin{array}{l}\text { 2.1. Speeding up } \\
\text { growth and } \\
\text { transforming the } \\
\text { economy to create } \\
\text { decent work and } \\
\text { sustainable livelihoods }\end{array}$ & & & & & & & & & & & & & & S2d & & & S2(3) & S2A & & & & & & \\
\hline $\begin{array}{l}\text { 2.2. Massive } \\
\text { programme to build } \\
\text { economic and social } \\
\text { infrastructure }\end{array}$ & & & & & & & & & & & & & & $\mathrm{s} 2 \mathrm{~d}$ & & & & S2A & & & & & & \\
\hline $\begin{array}{l}\text { 2.3. Comprehensive } \\
\text { rural development } \\
\text { strategy linked to land } \\
\text { and agrarian reform } \\
\text { and food security }\end{array}$ & & & & & & & & & & & & & & $\mathrm{Sj}$ & & & S2(3) & S2A & s3(2) & & & & & \\
\hline $\begin{array}{l}\text { 2.4. Strengthen the } \\
\text { skills and human } \\
\text { resource base }\end{array}$ & & & & $54 \mathrm{j}$ & & & & & & & & & & & & & & $\mathrm{S} 2 \mathrm{~A}$ & & & & & & \\
\hline $\begin{array}{l}\text { 2.5. Improve the } \\
\text { health profile of all } \\
\text { South Africans }\end{array}$ & Preamble & $5 \& 6$ & $3 \& 4$ & & & & & & & & Preamble & & 1 & S42L & $s 2 c$ & Preamble & & & s3(3) & & & $\begin{array}{c}S 4,5, \\
10\end{array}$ & Preamble & \\
\hline $\begin{array}{l}\text { 2.6. Intensify the fight } \\
\text { against crime and } \\
\text { corruption }\end{array}$ & & & & & & & Preamble & & & & & & & & & & & & & & & & & \\
\hline 2.7. Build cohesive, & & & & & & & & & & & & & & & & & & S2A & S3(2) & & & & & \\
\hline
\end{tabular}




\begin{tabular}{|c|c|c|c|c|c|c|c|c|c|c|c|c|c|c|c|c|c|c|c|c|c|c|c|c|}
\hline $\begin{array}{l}\text { South African priorities } \\
\text { and strategies }\end{array}$ & 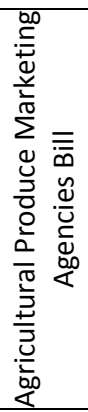 & 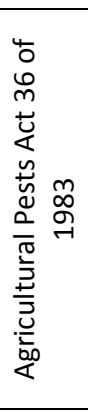 & 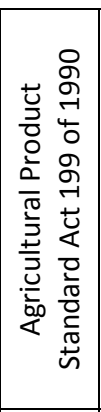 & 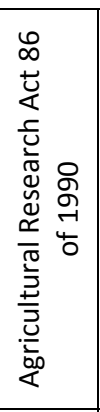 & 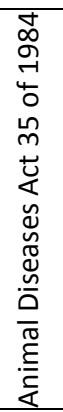 & 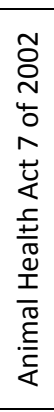 & 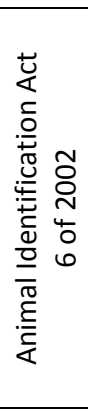 & 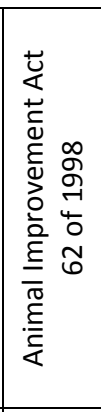 & 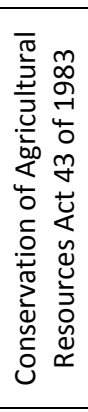 & 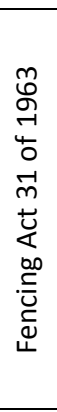 & 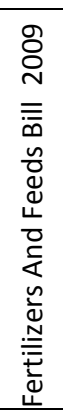 & 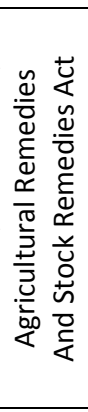 & 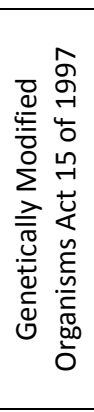 & 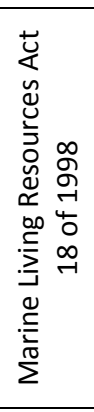 & 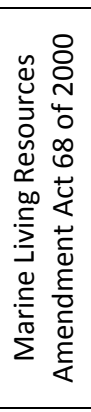 & 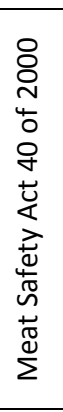 & 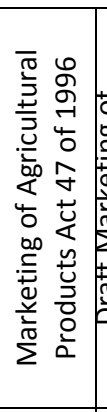 & 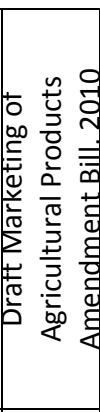 & 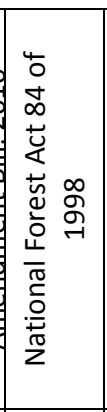 & 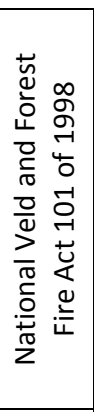 & 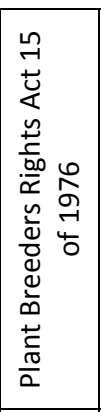 & 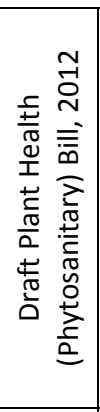 & 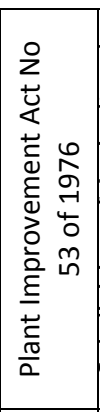 & 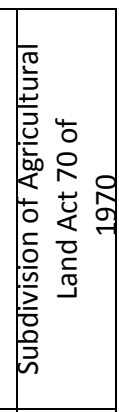 \\
\hline \multicolumn{25}{|l|}{$\begin{array}{l}\text { caring and sustainable } \\
\text { communities }\end{array}$} \\
\hline $\begin{array}{l}\text { 2.8. Pursuing African } \\
\text { advancement and } \\
\text { enhanced international } \\
\text { co-operation }\end{array}$ & & & & S4e & & & & & & & & & 1 & $\begin{array}{c}S 2 i \\
\& \\
S 2 j\end{array}$ & & & 3 & & & & & & & \\
\hline $\begin{array}{l}\text { 2.9. Sustainable } \\
\text { Resource Management } \\
\text { and use }\end{array}$ & & & & S4a (i) & & & & & $\begin{array}{c}\text { S5\& } \\
6\end{array}$ & & & & 1 & $\begin{array}{l}\text { S2a, } \\
\text { S2b, } \\
\text { S2f } \\
\& \\
\text { S2g }\end{array}$ & $\begin{array}{l}\text { S2a, } \\
\text { b, c, } \\
\text { d, e, } \\
f, g\end{array}$ & & & S2A & $\mathrm{S} 3(3)$ & & & & & \\
\hline $\begin{array}{l}\text { 2.10. Building a } \\
\text { developmental state } \\
\text { including improvement } \\
\text { of public services and } \\
\text { strengthening } \\
\text { democratic institutions }\end{array}$ & & & & & & & & & & & & & & & $S 2 i$ & & & S2A & & & & & & \\
\hline \multicolumn{25}{|l|}{$\begin{array}{l}\text { 3. RSA Government } \\
\text { Strategic Outcomes }\end{array}$} \\
\hline \multicolumn{25}{|l|}{$\begin{array}{l}\text { 4. Decent employment } \\
\text { through inclusive } \\
\text { economic growth }\end{array}$} \\
\hline $\begin{array}{l}\text { Outcome 4.1: Faster } \\
\text { and Sustainable } \\
\text { inclusive growth }\end{array}$ & & & & & & & & & & & & & & S2d & & & & S2A & & & & & & \\
\hline $\begin{array}{l}\text { Outcome 4.2: More } \\
\text { labour absorbing } \\
\text { growth }\end{array}$ & & & & & & & & & & & & & & $S 2 d$ & & & & S2A & & & & & & \\
\hline \multicolumn{25}{|l|}{$\begin{array}{l}\text { Outcome 4.3: Multi- } \\
\text { pronged strategy to } \\
\text { reduce youth } \\
\text { unemployment }\end{array}$} \\
\hline $\begin{array}{l}\text { Outcome 4.4: } \\
\text { Increased }\end{array}$ & & & & & & & & Preamble & & & & & & & & & & $\begin{array}{c}\mathrm{S} 2 \mathrm{~A} \\
3\end{array}$ & \begin{tabular}{|l|}
$29(4 f) \&$ \\
$S 29(4 g)$
\end{tabular} & & & & reamble & \\
\hline
\end{tabular}




\begin{tabular}{|c|c|c|c|c|c|c|c|c|c|c|c|c|c|c|c|c|c|c|c|c|c|c|c|c|}
\hline $\begin{array}{l}\text { South African priorities } \\
\text { and strategies }\end{array}$ & 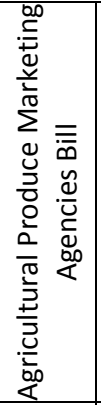 & 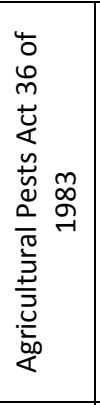 & 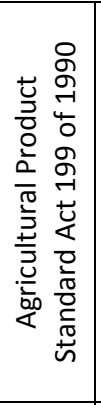 & 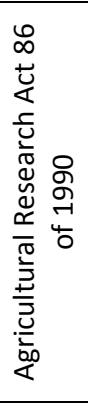 & 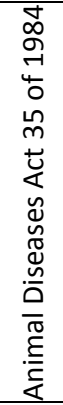 & 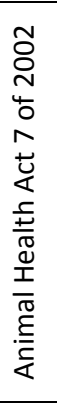 & 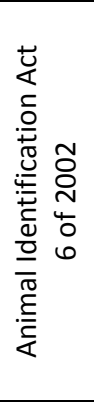 & 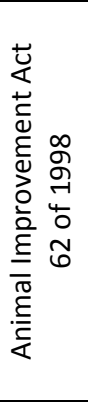 & 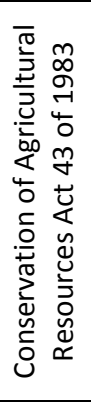 & 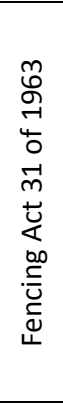 & 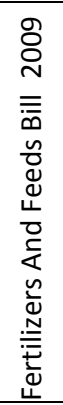 & 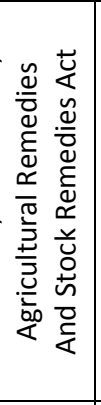 & 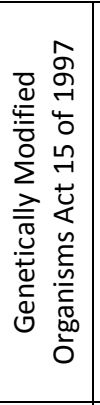 & 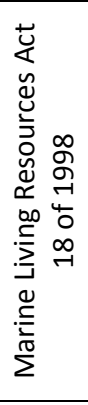 & 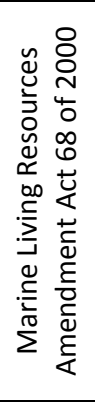 & 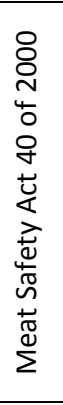 & 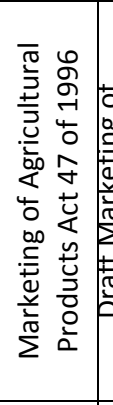 & 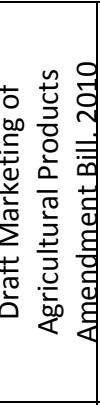 & 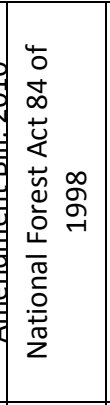 & 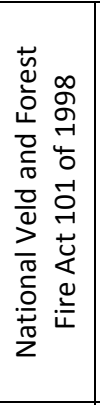 & 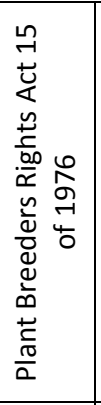 & 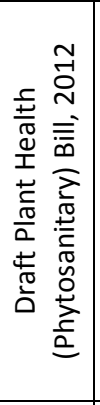 & 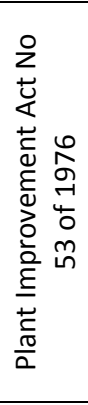 & 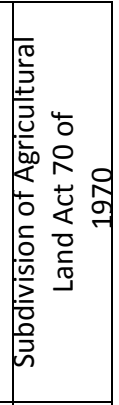 \\
\hline $\begin{array}{l}\text { competitiveness, to } \\
\text { raise net exports, road } \\
\text { trade as a share of } \\
\text { world trade and } \\
\text { improve its } \\
\text { composition }\end{array}$ & & & & & & & & & & & & & & & & & & & & & & & & \\
\hline $\begin{array}{l}\text { Outcome 4.5: Improve } \\
\text { cost structure in the } \\
\text { economy }\end{array}$ & & & & & & & & & & & & & & & & & & & & & & & & \\
\hline $\begin{array}{l}\text { Outcome 4.6: } \\
\text { Improved support to } \\
\text { small business and } \\
\text { cooperatives } \\
\end{array}$ & & & & & & & & & & & & & & & S2j & & & $\mathrm{S} 2 \mathrm{~A}$ & $\begin{array}{c}\text { Chapter } \\
3\end{array}$ & & & & & \\
\hline $\begin{array}{l}\text { 7. Vibrant, equitable } \\
\text { and sustainable rural } \\
\text { communities with food } \\
\text { security for all }\end{array}$ & & & & & & & & & & & & & & & & & & & & & & & & \\
\hline $\begin{array}{l}\text { Outcome 7.1: } \\
\text { Sustainable agrarian } \\
\text { reform }\end{array}$ & & & & & & & & & & & & & & 1 & & & & $\mathrm{~S} 2 \mathrm{~A}$ & Preamble & & & & & \\
\hline $\begin{array}{l}\text { Outcome 7.2: } \\
\text { Improved access to } \\
\text { affordable and diverse } \\
\text { food }\end{array}$ & & & & & & & & & & & & & & & & & & & & & & & & \\
\hline $\begin{array}{l}\text { Outcome 7.3: Rural } \\
\text { services and } \\
\text { sustainable livelihoods }\end{array}$ & & & & & & & & & & & & & & & & & & $\mathrm{S} 2 \mathrm{~A}$ & & & & & & \\
\hline $\begin{array}{l}\text { Outcome 7.4: Rural job } \\
\text { creation linked to skills } \\
\text { training and promoting } \\
\text { economic livelihoods }\end{array}$ & & & & & & & & & & & & & & & & & S2(3) & S2A & S3(2) & & & & & \\
\hline $\begin{array}{l}\text { Outcome 7.5: Enabling } \\
\text { institutional } \\
\text { environment for } \\
\text { sustainable and }\end{array}$ & & & & & & & & & & & & & & & $S 2 j$ & & 3 & S2A & $S 4(6 \mathrm{c})$ & & & & & \\
\hline
\end{tabular}




\begin{tabular}{|c|c|c|c|c|c|c|c|c|c|c|c|c|c|c|c|c|c|c|c|c|c|c|c|c|}
\hline $\begin{array}{c}\text { South African priorities } \\
\text { and strategies }\end{array}$ & 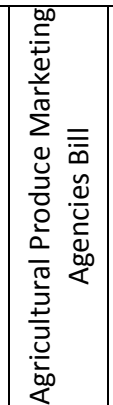 & 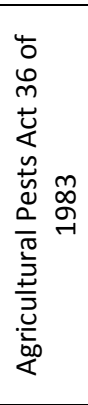 & 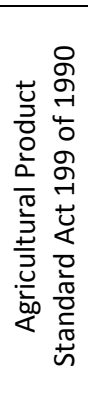 & 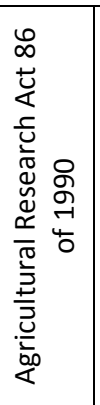 & 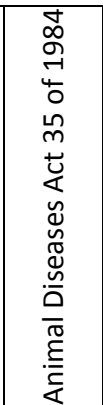 & 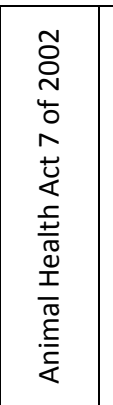 & 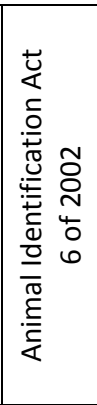 & 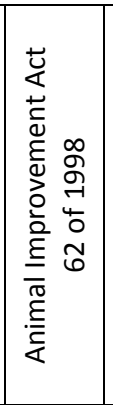 & 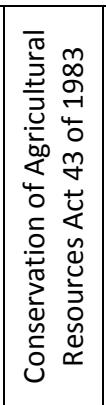 & 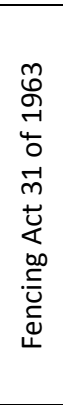 & 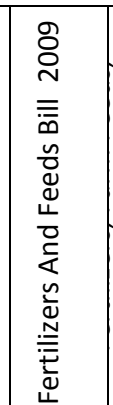 & 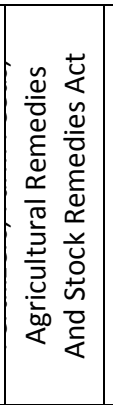 & 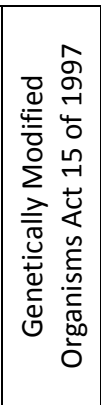 & 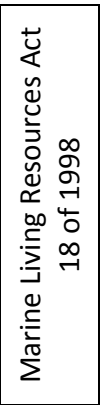 & 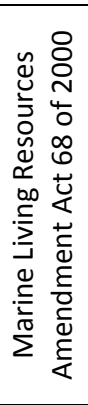 & 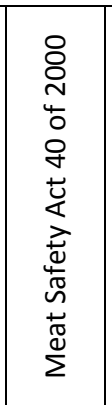 & 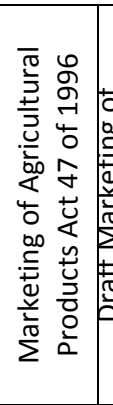 & 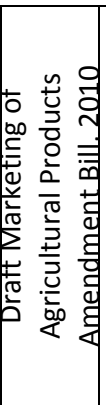 & 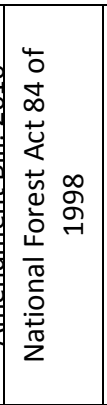 & 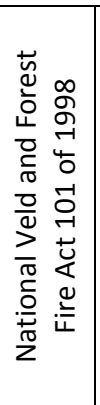 & 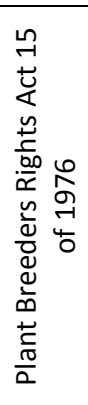 & 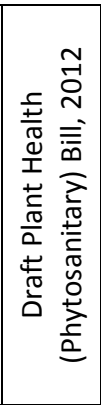 & 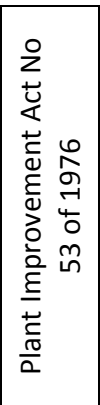 & 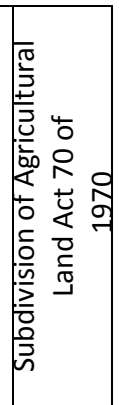 \\
\hline \multicolumn{25}{|l|}{ inclusive growth } \\
\hline \multicolumn{25}{|l|}{$\begin{array}{l}\text { 10. Environmental } \\
\text { assets and natural } \\
\text { resources that are well } \\
\text { protected and } \\
\text { continually enhanced }\end{array}$} \\
\hline $\begin{array}{l}\text { Outcome 10.1: } \\
\text { Enhanced quality and } \\
\text { quantity of water } \\
\text { resources }\end{array}$ & & & & & & & & & Preamble & & & & 1 & & $\begin{array}{l}\text { S2 a, } \\
\text { b, c, } \\
\text { d, e, } \\
\text { f, g }\end{array}$ & & & & $\mathrm{S} 3(3)$ & & & & & \\
\hline \multicolumn{25}{|l|}{$\begin{array}{l}\text { Outcome 10.2: } \\
\text { Reduced greenhouse } \\
\text { gas emissions, climate } \\
\text { change impacts and } \\
\text { improved } \\
\text { air/atmospheric quality }\end{array}$} \\
\hline $\begin{array}{l}\text { Outcome 10.3: } \\
\text { Sustainable } \\
\text { environmental } \\
\text { management }\end{array}$ & & & & $\mathrm{S} 4 \mathrm{a}(\mathrm{v})$ & & & & & $\begin{array}{c}\text { S3, } \\
5,6 \\
12 \\
15 \\
16 \\
\end{array}$ & & & & 1 & S2a & & & & & Preamble & & & S17 & & \\
\hline $\begin{array}{l}\text { Outcome 10.4: } \\
\text { Protected biodiversity }\end{array}$ & & & & & & & & & $\begin{array}{l}\text { S15 } \\
\& 16\end{array}$ & & & & 1 & $S 2 f$ & $S 2 f$ & & & & Preamble & & & S17 & & \\
\hline $\begin{array}{l}\text { 4. Bill of Rights } \\
\text { (Chapter 2) }\end{array}$ & Preamble & $5 \& 6$ & S7(3) & & Preamble & Preamble & & Preamble & & & Preamble & preamble & preamble & Preamble & S2i\&j & Preamble & 3 & $2 A$ & preamble & $S 4(6)$ & & $\begin{array}{c}S 4,5 \\
10\end{array}$ & reamble & \\
\hline
\end{tabular}


Appendix B: Matrix comparing Acts and Bills against the CAADP FAFS criteria

\begin{tabular}{|c|c|c|c|c|c|c|c|c|c|c|c|c|c|c|c|c|c|c|c|c|c|c|c|}
\hline Title of Act & 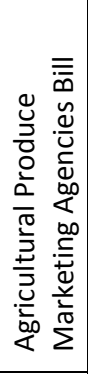 & 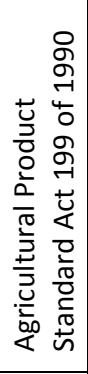 & 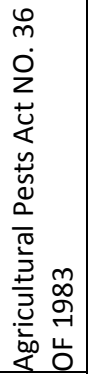 & 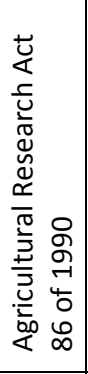 & 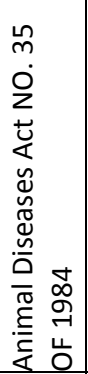 & 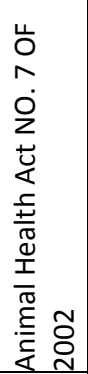 & 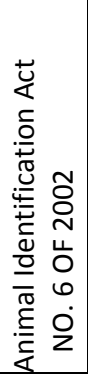 & 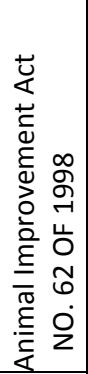 & 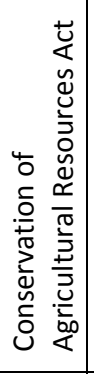 & 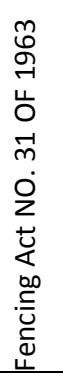 & 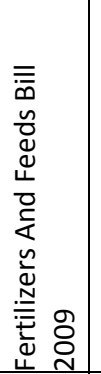 & 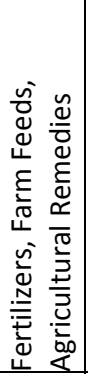 & 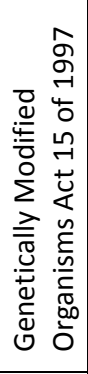 & 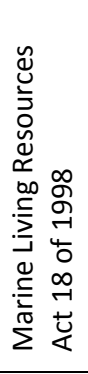 & 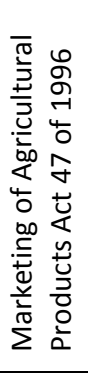 & 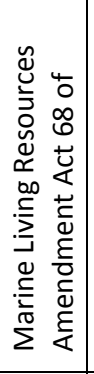 & 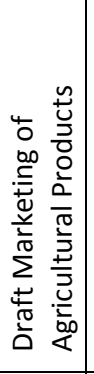 & 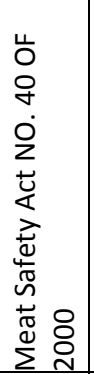 & 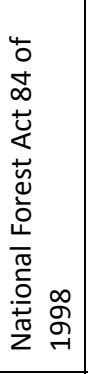 & 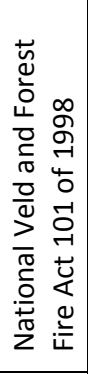 & 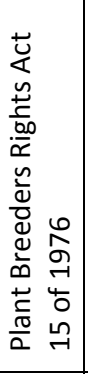 & 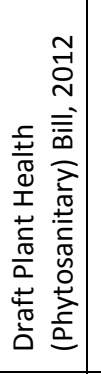 & 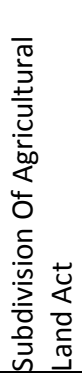 \\
\hline $\begin{array}{l}\text { Increase } \quad \text { economic } \\
\text { growth? }\end{array}$ & & $\mathrm{x}$ & & & & & & $x$ & & & $x$ & $x$ & $x$ & $x$ & $x$ & $x$ & $x$ & & & & $x$ & & \\
\hline $\begin{array}{l}\text { Increase opportunities } \\
\text { for producers and } \\
\text { marketers? }\end{array}$ & & $x$ & & & & & & $\mathrm{x}$ & & & $x$ & $\mathrm{x}$ & $\mathrm{x}$ & $\mathrm{x}$ & $\mathrm{X}$ & $x$ & $x$ & & & & $x$ & & \\
\hline $\begin{array}{l}\text { Exploit competitive } \\
\text { advantages across the } \\
\text { value chain? }\end{array}$ & & & & & & & & $x$ & & & & & $x$ & $\mathrm{X}$ & $x$ & $x$ & $x$ & & & & $x$ & & \\
\hline Improve productivity? & & & $x$ & & & & & $x$ & & & $x$ & $x$ & $x$ & $x$ & & $x$ & & $x$ & & & $x$ & $x$ & $x$ \\
\hline $\begin{array}{l}\text { Reduce risk and increase } \\
\text { resilience? }\end{array}$ & & $x$ & $x$ & & $x$ & $x$ & $x$ & & $\mathrm{X}$ & $x$ & $\mathrm{X}$ & $\mathrm{x}$ & $\mathrm{X}$ & $\mathrm{X}$ & $\mathrm{x}$ & $\mathrm{x}$ & $\mathrm{X}$ & $\mathrm{X}$ & $\mathrm{x}$ & $x$ & $\mathrm{x}$ & $x$ & $x$ \\
\hline $\begin{array}{l}\text { Increase supply of } \\
\text { affordable food? }\end{array}$ & & & & & & & & $\mathrm{X}$ & & & $\mathrm{X}$ & $\mathrm{X}$ & $\mathrm{X}$ & $\mathrm{X}$ & $\mathrm{X}$ & $x$ & $\mathrm{X}$ & & & & $\mathrm{X}$ & & \\
\hline $\begin{array}{l}\text { Increase incomes of the } \\
\text { poor? }\end{array}$ & & & & & & & & $x$ & $\mathrm{X}$ & & & & $x$ & $\mathrm{X}$ & & $x$ & & & & & $x$ & & \\
\hline $\begin{array}{l}\text { Reduce malnutrition or } \\
\text { increase dietary } \\
\text { diversity? }\end{array}$ & & & & & & & & & $x$ & & & & & $x$ & & $x$ & & & $x$ & & & & \\
\hline
\end{tabular}


Appendix C.

Summary table of food security related content of South African agricultural Acts and Bills (Hendriks and Olivier, 2014)

\begin{tabular}{|c|c|c|}
\hline Act & Purpose of the Act & Sections relevant to food security \\
\hline $\begin{array}{l}\text { Agricultural Pests Act } 36 \text { of } \\
1983\end{array}$ & $\begin{array}{l}\text { To provide for measures by which agricultural pests may be } \\
\text { prevented and combated; and for matters connected therewith. }\end{array}$ & 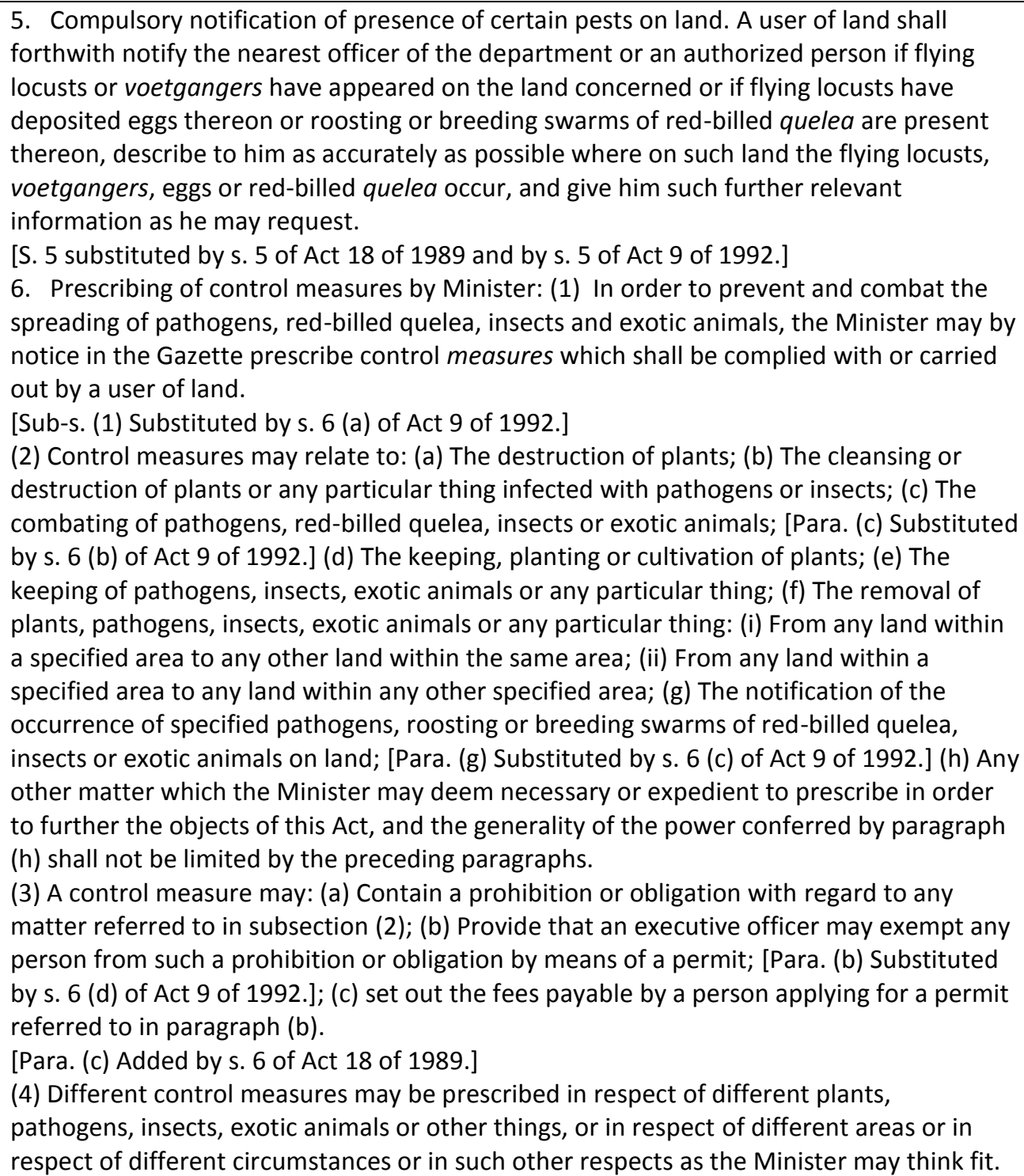 \\
\hline
\end{tabular}


Agricultural Produce Marketing Agency Fidelity Fund; to provide for the constitution of the Board of the Agricultural Produce

Marketing Agency; to make certain provisions applicable to all or certain categories of agricultural produce agents, auctioneers, brokers and wholesalers; to provide for the regulation of the occupations of auctioneers, brokers and wholesalers; to provide for the regulation of fresh produce markets; to provide for

compulsory training for all new and existing agricultural produce agents, auctioneers, brokers, wholesalers, sales persons and booking clerks; and to provide for compulsory registration and accreditation of all agricultural produce agents, auctioneers, brokers, wholesalers, sales persons and booking clerks; to repeal Agricultural Produce Agents Act, 1992; and to provide for matters connected therewith. 
Agricultural Product Standard Act 199 of 1990 practice may be instituted in terms of this Act.
To provide for control over the sale and export of certain agricultural products, control over the sale of certain imported agricultural products; and control over other related products; and for matters connected therewith.

\section{Sections relevant to food security}

3. Control over sale of products: (1) The Minister may: (a) Prohibit the sale of a prescribed product: (i) Unless that product is sold according to the prescribed class or grade; (ii) Unless that product complies with the prescribed standards regarding the quality thereof, or a class or grade thereof; (iii) Unless the prescribed requirements in connection with the management control system, packing, marking and labelling of that product are complied with; [Sub-paragraph. (iii) Substituted by s. 3 (a) of Act No. 63 of 1998.]; (iv) If that product contains a prescribed prohibited substance or does not contain a prescribed substance; and (v) Unless that product is packed, marked and labelled in the prescribed manner or with the prescribed particulars;

4. Control over export of products. (1) The Minister may: (a) Prohibit the export from the Republic of a prescribed product unless each quantity of that product, intended for export, has been approved by the executive officer for that purpose; (b) Determine that a prohibition referred to in paragraph (a) shall only apply to the export of a prescribed product to a prescribed country or for a prescribed purpose, or in a prescribed form or quantity, or under such other prescribed circumstances as the Minister deems necessary; and (c) Exclude the export of a prescribed product to a prescribed country or for a prescribed purpose, or in a prescribed form or quantity, from a prohibition referred to in paragraph (a).

(2) An application for an approval referred.

4A. Control over sale of imported products (1) The Minister may: (a) Prohibit the sale of a prescribed product imported into the Republic unless each quantity of such product intended for sale in the Republic complies with the provisions of section 3 (1); and (b) Determine by notice in the Gazette that a particular prescribed product imported for sale in the Republic shall not be removed from the prescribed port of entry or such other place as the executive officer may determine unless: (i) Each quantity of such product intended for sale in the Republic has been approved by the executive officer for that purpose; or (ii) Written permission for the removal of a particular quantity of such product has been granted by the executive officer on the conditions, which he or she deems necessary.

3. Control over sale of products. (1) The Minister may: (a) Prohibit the sale of a prescribed product: (i) Unless that product is sold according to the prescribed class or grade; (ii) Unless that product complies with the prescribed standards regarding the quality thereof, or a class or grade thereof; (iii) unless the prescribed requirements in connection with the management control system, packing, marking and labelling of that product are complied with; [Sub-para. (iii) substituted by s. 3 of Act 63/98]; ; (iv) if that product contains a prescribed prohibited substance or does not contain a prescribed substance; and ( $v$ ) unless that product is packed, marked and labelled in the prescribed manner or with the prescribed particulars; (b) determine that a prohibition referred to in paragraph (a) shall apply only to a prescribed category of persons or in a prescribed area, or exclude a prescribed category of persons or a prescribed area from such 


\begin{tabular}{|c|c|c|}
\hline Act & Purpose of the Act & Sections relevant to food security \\
\hline $\begin{array}{l}\text { Agricultural Research Act } \\
86 \text { of } 1990\end{array}$ & $\begin{array}{l}\text { To establish a juristic person to deal with agricultural research; to } \\
\text { determine its objects, functions, powers and duties; to prescribe } \\
\text { the manner in which it is to be managed and governed; to } \\
\text { regulate its employee matters and financial affairs; and to } \\
\text { provide for matters connected therewith. }\end{array}$ & $\begin{array}{l}\text { 3. Objects of ARC. The objectives of the ARC are conduct research for development and } \\
\text { technology transfer, to promote agriculture and industry, contributing to the } \\
\text { improvement of the quality of life of the people of the Republic, and having regard to the } \\
\text { protection of the environment to perform such other functions as may be assigned to the } \\
\text { ARC by or under this Act. }\end{array}$ \\
\hline $\begin{array}{l}\text { Animal Diseases Act } 35 \text { of } \\
1984\end{array}$ & $\begin{array}{l}\text { To provide for the control of animal diseases and parasites, for } \\
\text { measures to promote animal health, and for matters connected } \\
\text { therewith. }\end{array}$ & None. \\
\hline $\begin{array}{l}\text { Animal Health Act } 7 \text { of } \\
2002\end{array}$ & $\begin{array}{l}\text { To provide for measures to promote animal health and to control } \\
\text { animal diseases; to assign executive authority with regard to } \\
\text { certain provisions of this Act to provinces; to regulate the } \\
\text { importation and exportation of animals and things; to establish } \\
\text { animal health schemes; and to provide for matters connected } \\
\text { therewith. }\end{array}$ & None. \\
\hline $\begin{array}{l}\text { Animal Identification Act } 6 \\
\text { of } 2002\end{array}$ & $\begin{array}{l}\text { To consolidate the law relating to the identification of animals } \\
\text { and to provide for incidental matters. }\end{array}$ & None. \\
\hline $\begin{array}{l}\text { Animal Improvement Act } \\
62 \text { of } 1998\end{array}$ & $\begin{array}{l}\text { To provide for the breeding, identification and utilisation of } \\
\text { genetically superior animals in order to improve the production } \\
\text { and performance of animals in the interest of the Republic; and } \\
\text { to provide for matters connected therewith. }\end{array}$ & None. \\
\hline $\begin{array}{l}\text { Conservation of } \\
\text { Agricultural Resources Act } \\
43 \text { of } 1983\end{array}$ & $\begin{array}{l}\text { To provide for control over the utilization of the natural } \\
\text { agricultural resources of the Republic in order to promote the } \\
\text { conservation of the soil, the water sources and the vegetation } \\
\text { and the combating of weeds and invader plants; and for matters } \\
\text { connected therewith. }\end{array}$ & $\begin{array}{l}\text { 5. Prohibition of the spreading of weeds. (1) No person shall: (a) sell, agree to sell or } \\
\text { offer, advertise, keep, exhibit, transmit, send, convey or deliver for sale, or exchange for } \\
\text { anything or dispose of to any person in any manner for a consideration, any weed; or (b) } \\
\text { in any other manner whatsoever disperse or cause or permit the dispersal of any weed } \\
\text { from any place in the Republic to any other place in the Republic. } \\
\text { 6. Control measures. (1) In order to achieve the objects of this Act the Minister may } \\
\text { prescribe control measures which shall be complied with by land users to whom they } \\
\text { apply. } \\
\text { (2) Such control measures may relate to: (a) The cultivation of virgin soil; (b) The } \\
\text { utilization and protection of land which is cultivated; (c) The irrigation of land; (d) The } \\
\text { prevention or control of waterlogging or salination of land; (e) The utilization and } \\
\text { protection of vleis, marshes, water sponges, water courses and water sources; (f) The } \\
\text { regulating of the flow pattern of run-off water; (g) The utilization and protection of the } \\
\text { vegetation; (h) The grazing capacity of veld, expressed as an area of veld per large stock } \\
\text { unit; (i) The maximum number and the kind of animals which may be kept on veld; (j) The } \\
\text { prevention and control of veld fires; (k) The utilization and protection of veld which has } \\
\text { burned; (l) The control of weeds and invader plants; (m) The restoration or reclamation of } \\
\text { eroded land or land which is otherwise disturbed or denuded; ( } \mathrm{n} \text { ) The protection of water } \\
\text { sources against pollution on account of farming practices; (o) The construction, }\end{array}$ \\
\hline
\end{tabular}


12. Maintenance of soil conservation works and maintenance of certain states of affairs. (1) (a) A soil conservation work shall, except where otherwise provided in this Act or a scheme, be maintained by every land user of the land concerned and his successor in title at his own expense in a manner which, in the opinion of the executive officer, will ensure the continued efficiency thereof; (b) The state of affairs arising on any land after any act has been performed thereon or in respect thereof in order to achieve the objects of this Act, shall be maintained in such manner as in the opinion of the executive officer will obviate the necessity of a repetition of that act.

14. Expropriation of land for purposes of restoration or reclamation. (1) If the Minister is of opinion that it is necessary for the restoration or reclamation of the natural agricultural resources of any land in order to achieve the objects of this Act, he may expropriate that land; (2) The provisions of the Expropriation Act 63 of 1975, shall mutatis mutandis apply with reference to the expropriation of land under subsection (1) of this section.

15. Conservation committees. (1) The Minister may establish a committee, to be known as a conservation committee, in respect of any area determined by the Minister; (2) A conservation committee so established for any area: (a) Shall promote the conservation of the natural agricultural resources in the area concerned in order to achieve the objects of this Act on or with regard to the land in that area; (b) Shall advise the department on any matter as to the application of this Act or a scheme in the area concerned, or which it may deem necessary in order that the objects of this Act may be achieved in the area

concerned; and (c) May exercise such other powers and shall perform such other duties as may be conferred or imposed upon it by or in terms of this Act or by the Minister; (3) (a)

The members of a conservation committee shall be appointed by the Minister.

16. Regional conservation committees. (1) The Minister may establish in respect of any region determined by him, a committee to be known as a regional conservation committee. (2) A regional conservation committee so established in respect of a particular region shall: (a) Advise every conservation committee in the region concerned on matters regarding the conservation of the natural agricultural resources; (b) Advise the department and the advisory board on any matter arising from the application of this Act or a scheme in the region concerned, or which it may deem necessary in order that the objects of this Act may be achieved in that region; and (c) Perform such other duties as may be imposed upon it by the Minister. (3) (a) The members of a regional conservation 


\begin{tabular}{|l}
\hline Act \\
\hline Draft Marketing of
\end{tabular}

Agricultural Products

Amendment Bill, 2010

\section{Purpose of the Act}

\section{Amendment of section 2 of Act 47 of 1996}

2. Section 2 of the principal Act is hereby amended by: (a) the substitution for subsection (2) of the following subsection:

The objectives of this Act are: (a) The increasing of market access for all market participants [;] by identifying areas of focus and intervention such as provision of agricultural marketing information, agro-logistics and agricultural marketing infrastructure, agricultural marketing skills and any other relevant intervention and marketing support program; (b) The promotion of efficiency of the marketing of agricultural products [;] in the case of market failures and through monitoring uncompetitive practices in the market; (c) The optimization of export earnings from agricultural products [;], that will accrue through the establishment of an agricultural trade support measures such as trade research, trade diplomacy, regulatory services, export councils and any other forum that can be utilized for this purpose;

(d) The enhancement of the viability of the agricultural sector [.] through diversification, value addition, creation of new rural agro-industries and innovation in the agro-food value chains; (e) The establishment of an agricultural economic and market research program aimed at enhancing the competitiveness of South African Agricultural sector in global value chains/markets; and (f) The creation of a provision for the implementation of trade agreements and trade measures relating to agriculture.

\section{Draft Plant Health}

(Phytosanitary) Bill, 2012

\section{To provide for:}

- Phytosanitary measures to prevent the introduction, establishment and spread of regulated pests in the Republic;

- For the control of regulated pests;

- For regulation of the movement of plants, plant products and other regulated articles into, within and out of the Republic; As well as to provide for matters connected therewith.
Sections relevant to food security

committee shall be appointed.

Insertion of Section 2A in Act 47 of 1996 (3) The principal Act is hereby amended by the

insertion after section 2 of the following section:

\section{"The role of the Department in agricultural marketing}

2A. (1) The Director of Marketing in the National Department and Directors of Agricultural Economics and Marketing in the Provincial Departments shall:

(a) Promote and facilitate the establishment of commodity associations/groups and agricultural marketing cooperatives for developing and new farmers and facilitate their integration with the mainstream commercial commodity associations;

(b) Establish agricultural marketing support programs to support developing and new farmers and agri-businesses;

(c) Implement an agricultural marketing skills development program to assist developing and new farmers to effectively participate in agricultural markets;

(d) Collect, analyse and disseminate agricultural marketing information to all roleplayers across the value chain;

(e) Facilitate development and implementation of a program of linking farmers to agricultural markets in collaboration with the industry;

(f) Promote and facilitate investment in critical agricultural marketing infrastructure to facilitate value addition and agro-processing;

(g) Facilitate access to logistics network to link smallholder farmers with mainstream markets;

(h) Investigate the requests for establishment, continuation, amendment or repeal of statutory measures; and

(i) Monitor the use of agricultural industry trust funds and manage the reporting processes between the Minister and the Ministerial Trustees."

\section{4. (1) The Minister may, out of funds appropriated by Parliament for that purpose,}

perform any act on or with respect to land that is necessary to: (a) Carry out the

provisions of a control measure or an order where the user of land concerned refuses or

neglects to do so; (b) Release on, or remove or eradicate from, land an organism imported

in terms of section 12(5); (c) Control regulated pests; and (d) Further the objectives of this Act. (2) The Minister may, on application, authorise a person or juristic person to perform at the expense of that person or juristic person and subject to the control and instruction of the Minister, the acts referred to in subsection (1) (a), and such a person or juristic person has no recourse against the State for expenses so incurred. (3) The Minister may, by notice in the Gazette, prescribe control measure which must be complied with or carried out by a user of land in terms of section 5 of this Act; 


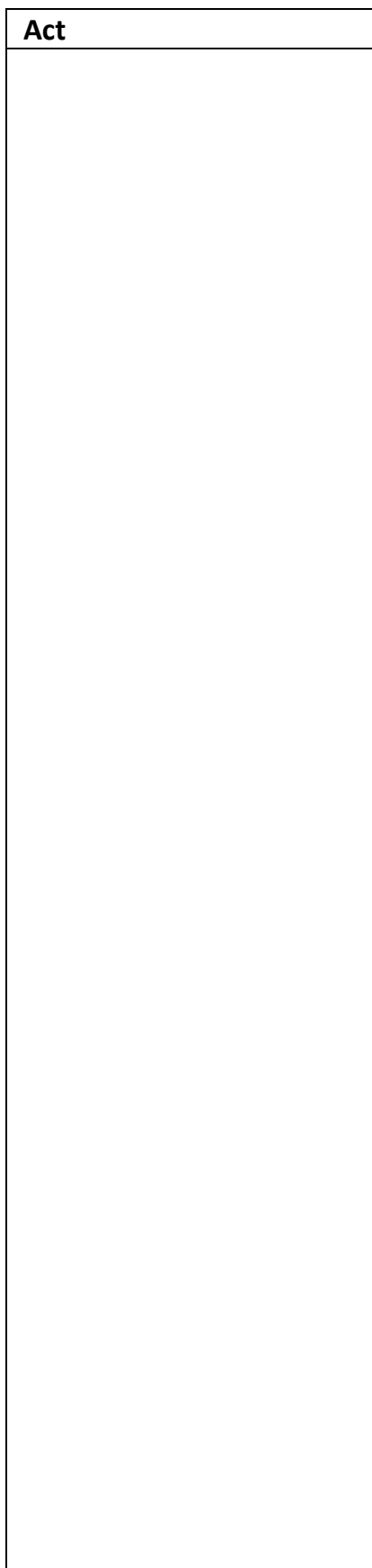

The Minister may make regulations in terms of section 26 of this Act; Prescribing of control measures by the Minister

5. (1) The Minister may, by notice in the Gazette, prescribe control measures, which must be complied with or carried out by a user of land. (2) Control measures may relate to: (a) The control of regulated pests; (b) The keeping, planting or cultivation of plants; (c) The keeping of regulated articles; (d) The removal of regulated articles from land within a specified area to (i) Other land within the same area; or (ii) Other land within any other specified area; (e) The notification of the occurrence of regulated pests; or (f) Any other matter which may be necessary or expedient to prescribe in order to further the objectives of this Act, and the generality of the power conferred by this paragraph may not be limited by the preceding paragraphs.

(3) Control measures must -

(a) Contain a prohibition or obligation with regard to any matter referred to in subsection (2);

(b) Provide that the executive officer may exempt a person from the prohibition or obligation by means of a permit; and

(c) Prescribe fees payable by a person applying for a permit referred to in subsection (3)(b);

Different control measures may be prescribed in respect of different regulated pests, different areas or different circumstances or in such other respect as may be necessary.

Designation of the National Plant Protection Organisation of South Africa (NPPOZA)

9. The competent phytosanitary policy and operational directorates of the Department shall serve as the NPPOZA in order to prevent the introduction, establishment and spread of pests of plants and plant products as well as promote appropriate measures for their control.

Functions of the NPPOZA

10. The NPPOZA shall perform the following functions -

(a) Providing a national plant protection contact point in terms of the IPPC in the Republic;

(b) Issuing phytosanitary certificates

(c) Conducting pest risk analyses; 


\begin{tabular}{|c|c|c|}
\hline Act & Purpose of the Act & Sections relevant to food security \\
\hline & & $\begin{array}{l}\text { (d) Issuing phytosanitary measures; } \\
\text { (e) Proposing, reviewing, and enforcing phytosanitary measures; } \\
\text { (f) Inspection of consignments of plants, plant products and other regulated articles; } \\
\text { (g) Notifying trading partners regarding non-compliance with phytosanitary import } \\
\text { requirements; } \\
\text { (h) Notifying other countries about the Republic's phytosanitary measures, regulations, } \\
\text { requirements and legislation; } \\
\text { (i) Conducting surveillance for regulated pests and/or national pests of concern in the } \\
\text { Republic; } \\
\text { (j) Conducting phytosanitary audits to ensure that pest management is in compliance with } \\
\text { official phytosanitary measures and standards; } \\
\text { (k) Rendering plant health services that include phytosanitary diagnostic services and } \\
\text { quarantine services; } \\
\text { (l) Distribute plant health information regarding regulated pests and any other } \\
\text { phytosanitary matters that are of public interest; } \\
\text { (m) conducting training and development of staff; } \\
\text { (n) representing the Republic in bilateral, regional and other international phytosanitary } \\
\text { forums; } \\
\text { (o) negotiating and maintaining export work programmes, bilateral protocols for } \\
\text { importing and exporting plants and plant products and other regulated articles; as well as } \\
\text { any other related phytosanitary measures; and } \\
\text { (p) any other functions as may be required by the provisions of this Act and relevant } \\
\text { international agreements. } \\
\text { Compulsory notification of presence of pests } \\
\text { 17. (1) A user of land who knows or suspects the presence of regulated pests or national } \\
\text { pests of concern have appeared on the land concerned must - } \\
\text { (a) Immediately notify the executive officer by the quickest practicable means; } \\
\text { (b) Provide the executive officer with such further information as the executive officer } \\
\text { may reasonably require; and } \\
\text { (c) Take all reasonable measures to prevent the spread of the regulated pests or national } \\
\text { pests of concern. } \\
\text { (2) } \\
\text { in the Republic must immediately report it to the executive officer and/or authority. }\end{array}$ \\
\hline $\begin{array}{l}\text { Fencing Act } \\
\text { NO. } 31 \text { OF } 1963\end{array}$ & $\begin{array}{l}\text { To consolidate the laws relating to fences and the fencing of } \\
\text { farms and other holdings and matters incidental thereto. }\end{array}$ & \\
\hline $\begin{array}{l}\text { Fertilizers And Feeds Bill } \\
\text { Bill first published in the } \\
\text { Government Gazette No. }\end{array}$ & $\begin{array}{l}\text { To provide for the licensing of facilities and rendering plants; to } \\
\text { provide for the registration of feed additives, raw materials, } \\
\text { animal by-products, imported fertilizers, feeds or pet foods, and }\end{array}$ & $\begin{array}{l}\text { RECOGNISING- } \\
* \text { The need to ensure safe fertilizer and feed production for food; } \\
* \text { The need to ensure the availability of safe and efficacious additives and raw material for }\end{array}$ \\
\hline
\end{tabular}




\begin{tabular}{|c|c|c|}
\hline Act & Purpose of the Act & Sections relevant to food security \\
\hline $\begin{array}{c}1131 \text { of } 21 \text { August } 2009 \text { for } \\
\text { public comments) }\end{array}$ & $\begin{array}{l}\text { home mixers; to provide for the appointment of a Registrar to } \\
\text { administer the Act; to provide for the establishment of the } \\
\text { Technical Standards Advisory Council; to provide for the } \\
\text { designation of technical advisers, analysts and auditors; to } \\
\text { provide for the regulation of the import, export, acquisition, } \\
\text { disposal, sale or use of fertilizers and feeds; to repeal certain laws } \\
\text { relating to fertilizers, feeds and sterilizing plants; and to provide } \\
\text { for matters connected therewith. }\end{array}$ & $\begin{array}{l}\text { use in the manufacture of compound fertilizers and feeds; } \\
\text { * The critical role of fertilizers and feeds in food safety and food security; } \\
\text { * The need for a traceability system within the fertilizer and feed industries; } \\
\text { * The need for supporting fertilizer, feed and rendering enterprises competing in the fast } \\
\text { moving consumer goods industry and for public policy objectives which promote } \\
\text { compliance with issues in terms of animal, human and environmental health; } \\
\text { AND IN ORDER TO- } \\
\text { * Disseminate an efficient and effective traceability system to; } \\
\text { * Ensure compliance with food safety requirements; } \\
\text { * Improve food security through availability of safe and efficacious fertilizers and feeds; } \\
\text { * Protect the consumers and users of fertilizers and feeds; } \\
\text { * Enhance product liability and consumer protection; and } \\
\text { * Ensure compliance with matters that relate to animal, human and environmental health, }\end{array}$ \\
\hline $\begin{array}{l}\text { Fertilizers, Farm Feeds, } \\
\text { Agricultural Remedies } \\
\text { And Stock Remedies Act } \\
\text { NO. } 36 \text { OF } 1947\end{array}$ & $\begin{array}{l}\text { To provide for the appointment of a Registrar of Fertilizers, Farm } \\
\text { Feeds, Agricultural Remedies and Stock Remedies; for the } \\
\text { registration of fertilizers, farm feeds, agricultural remedies, stock } \\
\text { remedies, sterilizing plants and pest control operators; to } \\
\text { regulate or prohibit the importation, sale, acquisition, disposal or } \\
\text { use of fertilizers, farm feeds, agricultural remedies and stock } \\
\text { remedies; to provide for the designation of technical advisers and } \\
\text { analysts; and to provide for matters incidental thereto. }\end{array}$ & \\
\hline $\begin{array}{l}\text { Genetically Modified } \\
\text { Organisms Act } 15 \text { of } 1997\end{array}$ & $\begin{array}{l}\text { To provide for measures to promote the responsible } \\
\text { development, production, use and application of genetically } \\
\text { modified organisms; to provide for an adequate level of } \\
\text { protection during all activities involving genetically modified } \\
\text { organisms that may have an adverse impact on the conservation } \\
\text { and sustainable use of biological diversity, human and animal } \\
\text { health; to give attention to the prevention of accidents and the } \\
\text { effective management of waste; to establish common measures } \\
\text { for the evaluation and reduction of the potential risks arising out } \\
\text { of activities involving the use of genetically modified organisms; } \\
\text { to lay down the necessary requirements and criteria for } \\
\text { scientifically based risk assessments, environmental impact } \\
\text { assessments, socio-economic considerations and risk } \\
\text { management measures; to establish a Council for genetically } \\
\text { modified organisms; to ensure that genetically modified } \\
\text { organisms are appropriate and do not present a hazard to the } \\
\text { environment; and to establish appropriate procedures for the } \\
\text { notification of specific activities involving the use of genetically }\end{array}$ & $\begin{array}{l}\text { "genetically modified organism" means an organism the genes or genetic material of } \\
\text { which has been modified in a way that does not occur naturally through mating or natural } \\
\text { recombination or both, and "genetic modification" shall have a corresponding meaning; }\end{array}$ \\
\hline
\end{tabular}




\begin{tabular}{|c|c|c|}
\hline Act & Purpose of the Act & Sections relevant to food security \\
\hline & $\begin{array}{l}\text { modified organisms; and to provide for matters connected } \\
\text { therewith. }\end{array}$ & \\
\hline $\begin{array}{l}\text { Marine Living Resources } \\
\text { Act } 18 \text { of } 1998\end{array}$ & $\begin{array}{l}\text { To provide for the conservation of marine ecosystems, the long- } \\
\text { term sustainable utilisation of marine living resources, orderly } \\
\text { access to opportunities to culture, harvest and use certain marine } \\
\text { living resources; and for these purposes to provide for the } \\
\text { exercise of control over marine living resources in a fair and } \\
\text { equitable manner to the benefit of all the citizens of South Africa; } \\
\text { and to provide for matters connected therewith. }\end{array}$ & 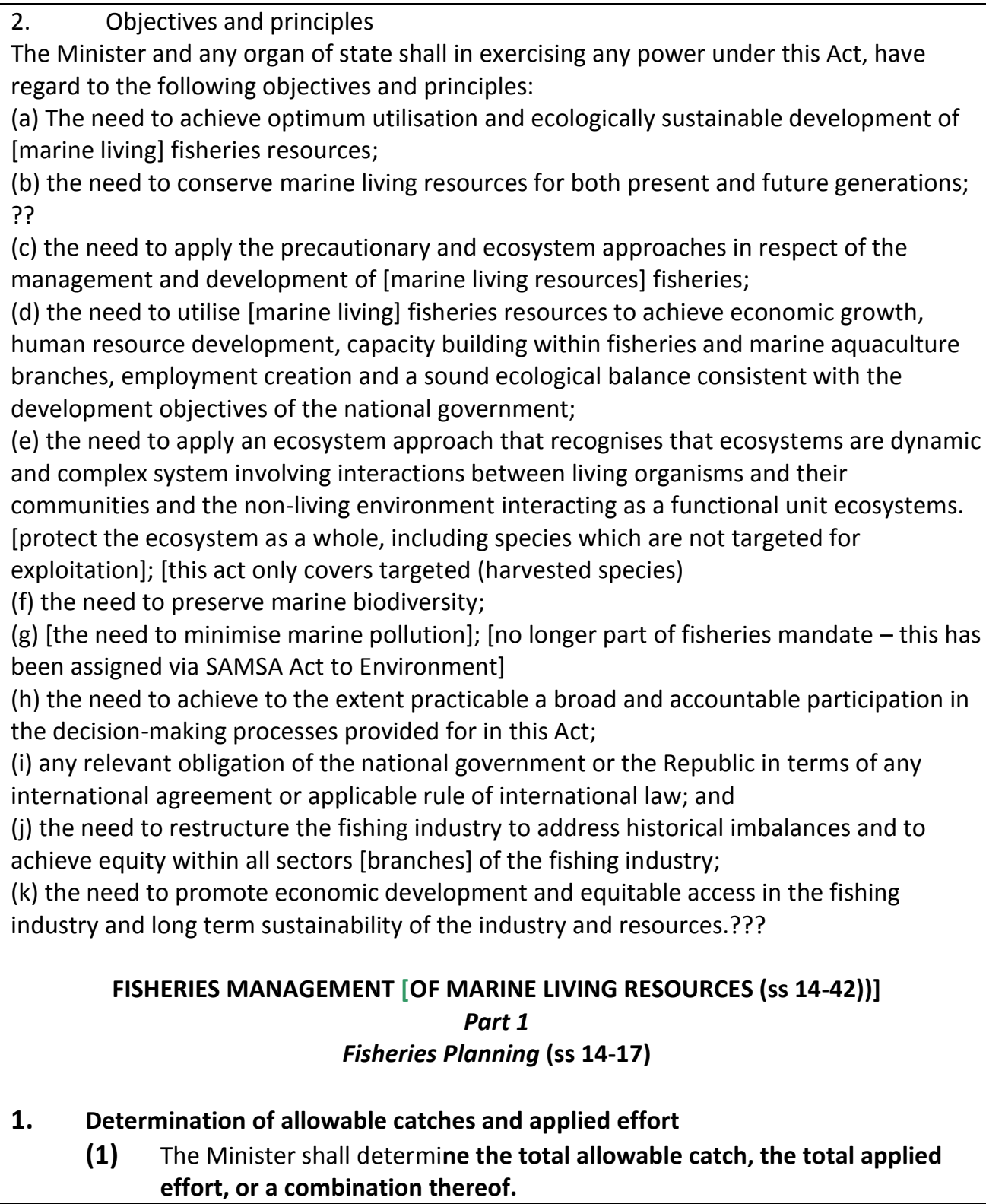 \\
\hline
\end{tabular}




\begin{tabular}{|c|c|c|c|}
\hline Act & Purpose of the Act & \multicolumn{2}{|c|}{ Sections relevant to food security } \\
\hline & & 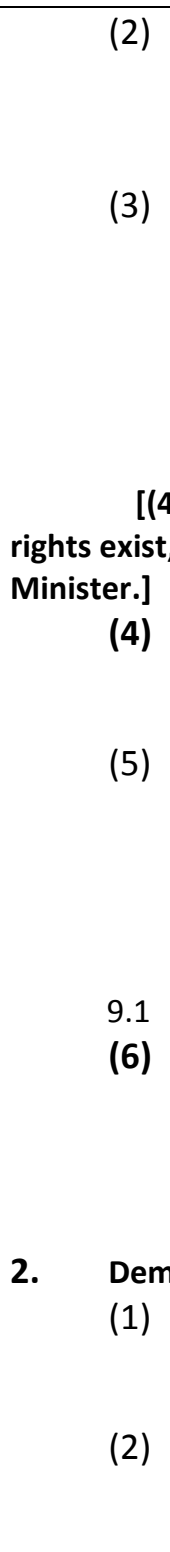 & $\begin{array}{l}\text { The Minister shall determine the portions of the total allowable catch, the } \\
\text { total applied effort, or a combination thereof, to be allocated in any year to } \\
\text { subsistence, small-scale, recreational, local commercial and foreign fishing, } \\
\text { respectively. } \\
\text { In the execution of his or her powers in terms of this section, the Minister } \\
\text { may determine that the total allowable catch, or the total applied effort, or } \\
\text { a combination thereof, shall apply- } \\
\text { (a) in a particular area, or in respect of particular species or a group of } \\
\quad \text { species of fish; and } \\
\text { (b) in respect of the use of particular gear, fishing methods or types of } \\
\quad \text { fishing vessels. } \\
\text { If the allowable commercial catch in respect of which commercial fishing } \\
\text { ncreases, the mass of the increase shall be available for allocation by the } \\
\text { The Minister may, in the event of any surplus of fish after the total allowable } \\
\text { catch or total applied effort was determined, allocate the surplus to existing } \\
\text { or new right holders. }{ }^{1} \\
\text { The provisions of this section shall not be construed to mean that the } \\
\text { Minister is prohibited from determining that- } \\
\text { (a) The total allowable catch; } \\
\text { (b) A portion of the total allowable catch contemplated in subsection (2); or } \\
\text { (c) An allocation in terms of subsection (4), } \\
\text { Shall be nil. } \\
\text { The Minister may, before or after acting in terms of subsection (5), declare a } \\
\text { total allowable catch, a portion of the total allowable catch in subsection (2) } \\
\text { or an allocation in terms of subsection (4), available for allocation but must } \\
\text { consider the objectives referred to in section } 2 \text { prior to such declaration. } \\
\text { rcated zones [Fisheries management areas] } \\
\text { The Minister may by notice in the Gazette declare any area of the South } \\
\text { African waters to be a demarcated zone [fisheries management area] for } \\
\text { the management of the species described in the notice. } \\
\text { The Minister may in respect of each demarcated zone [fisheries } \\
\text { management area] approve a plan for the conservation, management and } \\
\text { development of the fisheries. }\end{array}$ \\
\hline
\end{tabular}

\footnotetext{
${ }^{1}$ Reference to "existing or new right holders" may be deleted to allow the Minister a wide discretion in allocating the surplus. Drafting note: section $14(5)$ does not refer to "total applied effort" is this an omission or does that section only apply to total allowable catch?

${ }^{2}$ Drafting note: need instructions as to whether or not "total applied effort" should also be included.
} 


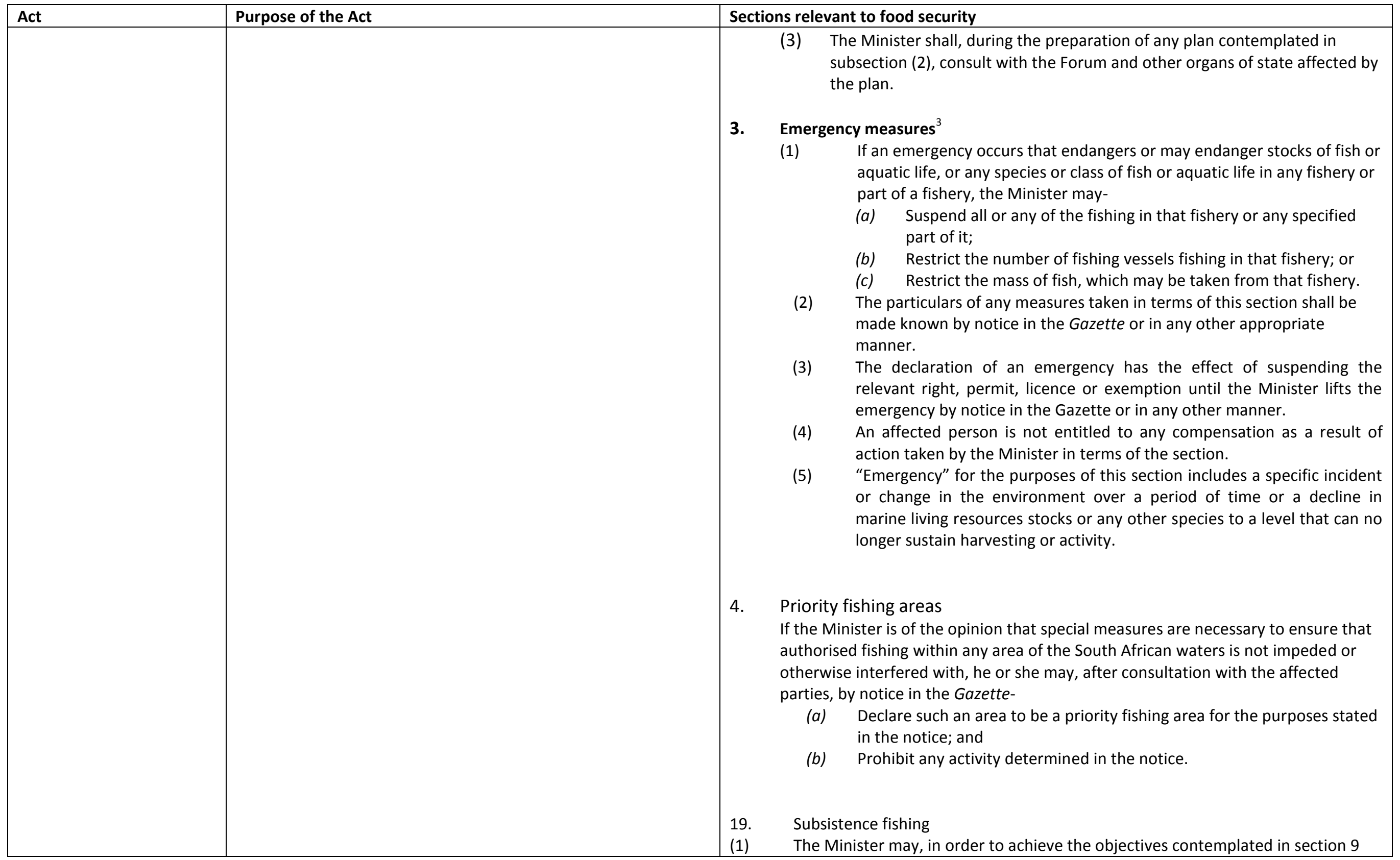

\footnotetext{
${ }^{3}$ This section is adapted from section 30 of NEMA.
} 


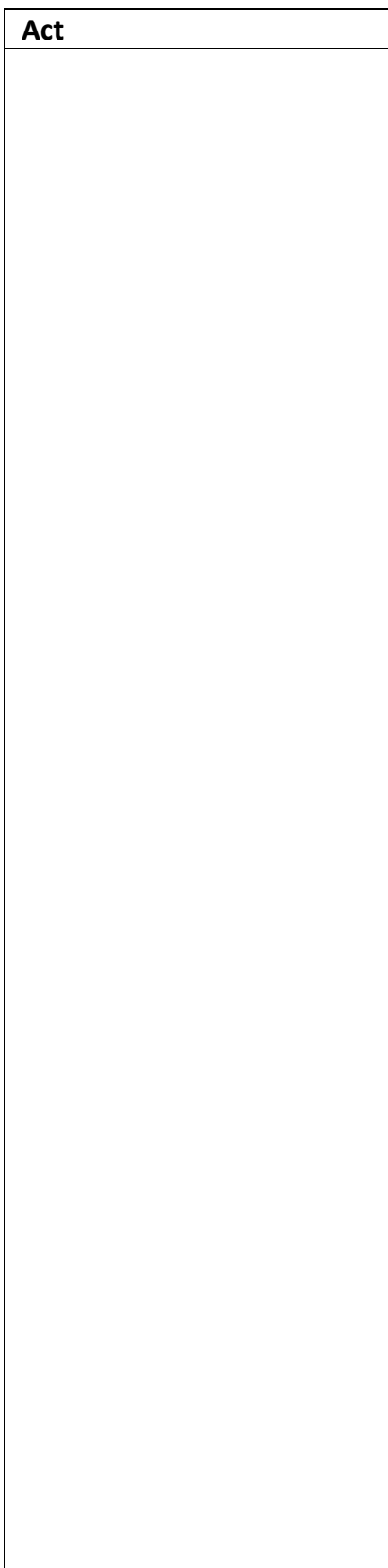

(2) of the Constitution, by notice in the Gazette-

(a) Establish areas or zones where subsistence fishers may fish; and

(b) After consultation with the Forum, declare-

(i) A specified community to be a fishing community, from which inhabitants may

be declared to be subsistence fishers; or

(ii) Any other person to be a subsistence fisher; or

(iii) Any other fishing or related activity or the exercise of any other right in that area or zone to be prohibited.

(c) No subsistence fishing right or permit shall be transferable except with the approval of and subject to the conditions determined by the Minister.

\section{A Small-scale fishing}

(1) The Minister -

(a) Must prescribe methods and gear which are approved for small-scale fishing purposes; and

(b) May prescribe methods or gear, which may not be used by any person engaged in small-scale fishing.

(2) A right or permit to undertake small-scale fishing is granted subject to the condition that the right or permit may be suspended or cancelled if the holder uses a method or gear that has not been approved by the Minister for the purposes of small-scale fishing. (a) (3) The holder of a right or permit to engage in small-scale fishing may, with the prior written approval of the Minister and in the manner which the Minister may prescribe, exercise the rights granted in terms of the right and permit in collaboration with other persons.

21. Commercial fishing

(1) Subject to the provisions of this Act, a commercial fishing right may be leased, divided or otherwise transferred.

(2) An application to transfer a commercial fishing right or a part thereof shall be submitted to the Minister in the manner that the Minister may determine, and subject to the provisions of this Act and any applicable regulation, the Minister may, in writing, approve the transfer of the right or a part thereof.

(3) The Minister may, after consultation with the Forum, make regulations regarding-

(a) The formula by which a commercial fishing right as a portion of the allowable commercial catch, the total applied effort, or a combination thereof, shall be determined; (b) Guidelines or criteria concerning the transfer of any right of access, including determining limits on the transfer of rights between holders of such rights on a temporary basis;

(c) The maximum or minimum portion of the allowable commercial catch, the total applied effort, or a combination thereof, which may be allocated or transferred to, or 


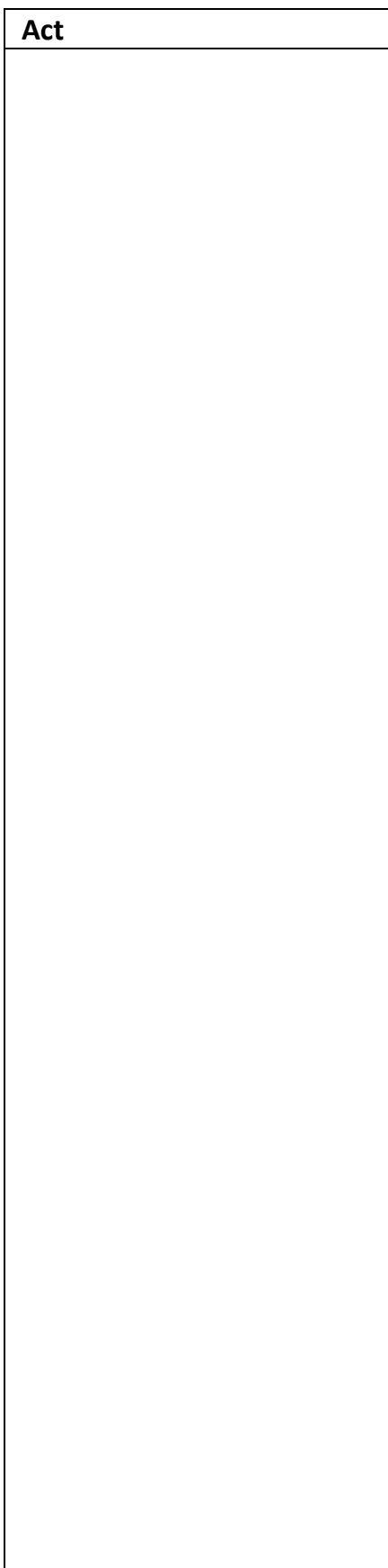

(d) Reallocation of any right of access, having regard to any significant alteration in the long-term revenue derived from the resource being exploited or in the long-term availability of the resource;

(e) The determination of rights to, or disposition of, by-catches in relation to any right;

(f) The monitoring and control of the use of rights of access;

(g) Subject to the provisions of the Labour Relations Act, 1995 (Act 66 of 1995), the employment of South African persons on board fishing vessels that are used for the utilisation of any right of access;

(h) The utilisation of South African fish processing establishments in the exercise of a right of access; and

(i) The other measures that may be necessary or desirable to achieve the effective implementation of a scheme for rights of access.

42J. Use of pharmaceuticals and chemicals

(1) No person shall use any chemical, pesticide, pharmaceutical, bio-remediation product, or its derivative, for marine aquaculture at marine aquaculture premises without first informing the marine aquaculture authority of the intended use and providing the marine aquaculture authority with any information in relation to the use of the substance as it may require.

(2) The marine aquaculture authority may by written notice to any person, restrict or prohibit that person from using any substance referred to in subsection (1) for the purposes of marine aquaculture or from using or permitting its use on marine aquaculture premises.

42K. Notification and disposal of potentially diseased marine living resources

(1) If the holder of a marine aquaculture permit, or the owner or occupier of any marine aquaculture premises, pet shop, commercial aquarium, research establishment or farm becomes aware that an unusually high number of marine living resources on the premises are diseased, infested with parasites or pests, or have died, that person shall notify a fishery control officer of the incident as soon as possible.

(2) A fishery control officer to whom an incident referred to in subsection (1) is reported must ensure that it is investigated as soon as reasonably possible in order to determine the likely cause of the disease, infestation or deaths and must advise the person who reported the incident of the findings of the investigation as soon as reasonably possible.

(3) Any person in control of marine aquaculture premises or of dead, diseased or infested marine living resources must comply immediately with any instructions given by a fishery control officer concerning how to dispose of dead marine living resources or how to treat diseased or infested marine living resources. 


\begin{tabular}{|c|c|c|}
\hline Act & Purpose of the Act & Sections relevant to food security \\
\hline & & $\begin{array}{l}\text { 42L. Notifiable diseases } \\
\text { (1) The Minister may prescribe that any disease (including a pest or parasite) that kills or } \\
\text { poses a risk to the health of, marine living resources, or to people or animals who eat the } \\
\text { infected marine living resources, is a notifiable disease. } \\
\text { (2) A person who knows or has reason to suspect that any marine living resource (whether } \\
\text { alive or dead) under their control is infected or infested with a notifiable disease must not } \\
\text { sell that marine living resource and must ensure that it is not eaten, does not enter coastal } \\
\text { waters and does not infest or infest other marine living resources. }\end{array}$ \\
\hline $\begin{array}{l}\text { Marine Living Resources } \\
\text { Amendment Act } 68 \text { of } 2000\end{array}$ & $\begin{array}{l}\text { To provide for the conservation of the marine ecosystem, the } \\
\text { long-term sustainable utilisation of marine living resources and } \\
\text { the orderly access to exploitation, utilisation and protection of } \\
\text { certain marine living resources; and for these purposes to provide } \\
\text { for the exercise of control over marine living resources in a fair } \\
\text { and equitable manner to the benefit of all the citizens of South } \\
\text { Africa; and to provide for matters connected therewith. }\end{array}$ & $\begin{array}{l}\text { 2. Objectives and principles } \\
\text { The Minister and any organ of state shall in exercising any power under this Act, have } \\
\text { regard to the following objectives and principles: } \\
\text { (a) The need to achieve optimum utilisation and ecologically sustainable development of } \\
\text { marine living resources; } \\
\text { (b) The need to conserve marine living resources for both present and future generations; } \\
\text { (c) The need to apply precautionary approaches in respect of the management and } \\
\text { development of marine living resources; } \\
\text { (d) The need to utilise marine living resources to achieve economic growth, human } \\
\text { resource development, capacity building within fisheries and mariculture branches, } \\
\text { employment creation and a sound ecological balance consistent with the development } \\
\text { objectives of the national government; } \\
\text { (e) The need to protect the ecosystem as a whole, including species which are not } \\
\text { targeted for exploitation; } \\
\text { (f) The need to preserve marine biodiversity; } \\
\text { (g) The need to minimise marine pollution; } \\
\text { (h) The need to achieve to the extent practicable a broad and accountable participation in } \\
\text { the decision making processes provided for in this Act; } \\
\text { (i) Any relevant obligation of the national government or the Republic in terms of any } \\
\text { international agreement or applicable rule of international law; and } \\
\text { (j) The need to restructure the fishing industry to address historical imbalances and to } \\
\text { achieve equity within all branches of the fishing industry. }\end{array}$ \\
\hline $\begin{array}{l}\text { Marketing of Agricultural } \\
\text { Products Act } 47 \text { of } 1996\end{array}$ & $\begin{array}{l}\text { To authorise the establishment and enforcement of regulatory } \\
\text { measures to intervene in the marketing of agricultural products, } \\
\text { including the introduction of levies on agricultural products; to } \\
\text { establish a National Agricultural Marketing Council; and to } \\
\text { provide for matters connected therewith. }\end{array}$ & $\begin{array}{l}\text { 2. Intervention in marketing of agricultural products. - (1) A statutory measure may only } \\
\text { be introduced in terms of this Act if the Minister is satisfied that such measure will directly } \\
\text { and substantially advance one or more of the objectives mentioned in subsection (2), } \\
\text { without being substantially detrimental to one or more of such objectives. } \\
\text { (2) The objectives of this Act are- } \\
\text { (a) The increasing of market access for all market participants; } \\
\text { (b) The promotion of the efficiency of the marketing of agricultural products; } \\
\text { (c) The optimisation of export earnings from agricultural products; } \\
\text { (d) The enhancement of the viability of the agricultural sector. }\end{array}$ \\
\hline
\end{tabular}




\begin{tabular}{|c|c|c|}
\hline Act & Purpose of the Act & Sections relevant to food security \\
\hline & & $\begin{array}{l}\text { (3) No statutory measure or prohibition in terms of section } 22 \text { which is likely to be } \\
\text { substantially detrimental to food security, the number of employment opportunities } \\
\text { within the economy or to fair labour. }\end{array}$ \\
\hline $\begin{array}{l}\text { Meat Safety Act } \\
\text { NO. } 40 \text { OF } 2000\end{array}$ & $\begin{array}{l}\text { To provide for measures to promote meat safety and the safety } \\
\text { of animal products; to establish and maintain essential national } \\
\text { standards in respect of abattoirs; to regulate the importation and } \\
\text { exportation of meat; to establish meat safety schemes; and to } \\
\text { provide for matters connected therewith. }\end{array}$ & \\
\hline $\begin{array}{l}\text { National Forest Act } 84 \text { of } \\
1998\end{array}$ & $\begin{array}{l}\text { To reform the law on forests; to repeal certain laws; and to } \\
\text { provide for related matters. }\end{array}$ & $\begin{array}{l}\text { Preamble. - Parliament recognises that- } \\
\text { - Everyone has the constitutional right to have the environment protected for the } \\
\text { benefit of present and future generations; } \\
\text { - Natural forests and woodlands form an important part of that environment and need } \\
\text { to be conserved and developed according to the principles of sustainable } \\
\text { management; } \\
\text { - Plantation forests play an important role in the economy; } \\
\text { - Plantation forests have an impact on the environment and need to be managed } \\
\text { appropriately; } \\
\text { - The State's role in forestry needs to change; and } \\
\text { - The economic, social and environmental benefits of forests have been distributed } \\
\text { unfairly in the past. } \\
\text { (3) The principles are that- } \\
\text { (a) Natural forests must not be destroyed save in exceptional circumstances where, in the } \\
\text { opinion of the Minister, a proposed new land use is preferable in terms of its economic, } \\
\text { social or environmental benefits; } \\
\text { (b) A minimum area of each woodland type should be conserved; and } \\
\text { (c) Forests must be developed and managed so as to- } \\
\text { (i) Conserve biological diversity, ecosystems and habitats; } \\
\text { (ii) Sustain the potential yield of their economic, social and environmental } \\
\text { benefits; } \\
\text { (iii) Promote the fair distribution of their economic, social, health and } \\
\text { environmental benefits; } \\
\text { (iv) Promote their health and vitality; } \\
\text { (v) Conserve natural resources, especially soil and water; } \\
\text { (vi) Conserve heritage resources and promote aesthetic, cultural and spiritual } \\
\text { values; and } \\
\text { (vii) Advance persons or categories of persons disadvantaged by unfair } \\
\text { discrimination. }\end{array}$ \\
\hline
\end{tabular}




\begin{tabular}{|c|c|c|}
\hline Act & Purpose of the Act & Sections relevant to food security \\
\hline & & $\begin{array}{l}\text { Part } 3 \\
\text { Community forestry } \\
\text { Part } 3 \text { allows communities that wish to engage in community forestry to enter into } \\
\text { agreements with the Minister. The procedure for entering into, and the minimum } \\
\text { requirements for the content of, such an agreement are set out. The Minister may make } \\
\text { financial or other assistance available for community forestry and certain other forms of } \\
\text { forestry. }\end{array}$ \\
\hline $\begin{array}{l}\text { National Veld and Forest } \\
\text { Fire Act } 101 \text { of } 1998\end{array}$ & $\begin{array}{l}\text { To reform the law on veld and forest fires; to repeal certain } \\
\text { provisions of the Forest Act, 1984; and to provide for related } \\
\text { matters. }\end{array}$ & \\
\hline $\begin{array}{l}\text { Plant Breeders Rights Act } \\
15 \text { of } 1976\end{array}$ & $\begin{array}{l}\text { To provide for a system where under plant breeders' rights } \\
\text { relating to varieties of certain kinds of plants may be granted and } \\
\text { registered; for the requirements which have to be complied with } \\
\text { for the grant of such rights; for the protection of such rights and } \\
\text { the grant of licences in respect of the exercise thereof; and to } \\
\text { provide for incidental matters. }\end{array}$ & \\
\hline $\begin{array}{l}\text { Plant Improvement Act } \\
\text { NO. } 53 \text { OF } 1976\end{array}$ & $\begin{array}{l}\text { To provide for the registration of premises from which the sale of } \\
\text { certain plants or the cleansing, packing and sale of certain } \\
\text { propagating material may be undertaken; to prescribe the } \\
\text { conditions subject to which such plants or propagating material } \\
\text { may be sold for the purposes of cultivation; to provide for the } \\
\text { recognition of certain varieties of plants; for a system of } \\
\text { certification of plants and propagating material with the object of } \\
\text { maintaining the quality of certain plants and propagating } \\
\text { material, and ensuring the usefulness of the products thereof for } \\
\text { agricultural and industrial purposes; and for the control of the } \\
\text { import and export of certain plants and propagating material; } \\
\text { and to provide for incidental matters. }\end{array}$ & \\
\hline $\begin{array}{l}\text { Subdivision Of Agricultural } \\
\text { Land Act } \\
\text { NO. } 70 \text { OF } 1970\end{array}$ & $\begin{array}{l}\text { To control the subdivision and, in connection therewith, the use } \\
\text { of agricultural land. }\end{array}$ & $\begin{array}{l}\text { This Act has been amended by the KwaZulu Land Affairs Act No. } 11 \text { of } 1992 \text { with effect } \\
\text { from } 11 \text { September } 1998 \text { insofar as it relates to KwaZulu. Please see the relevant } \\
\text { annotations for details of these amendments. }\end{array}$ \\
\hline
\end{tabular}

